\title{
Pro-Tumoral Inflammatory Myeloid Cells as Emerging Therapeutic Targets
}

\author{
Gabor J. Szebeni ${ }^{1,2, *}$, Csaba Vizler ${ }^{3}$, Lajos I. Nagy ${ }^{1}$, Klara Kitajka ${ }^{4}$ and Laszlo G. Puskas ${ }^{1,4}$ \\ 1 Avidin Ltd., Also kikoto sor 11/D., H-6726 Szeged, Hungary; lajos@avidinbiotech.com (L.I.N.); \\ laszlo@avidinbiotech.com or puskas.laszlo@brc.mta.hu (L.G.P.) \\ 2 Synaptogenex Ltd., Őzsuta utca 20995/1, H-1037 Budapest, Hungary \\ 3 Department of Biochemistry, Biological Research Center, Hungarian Academy of Sciences, Temesvari krt. 62., \\ H-6726 Szeged, Hungary; vizler.csaba@brc.mta.hu \\ 4 Department of Genetics, Biological Research Center, Hungarian Academy of Sciences, Temesvari krt. 62., \\ H-6726 Szeged, Hungary; klarakitajka@gmail.com \\ * Correspondence: g.szebeni@avidinbiotech.com; Tel.: +36-62-202-107
}

Academic Editors: Takuji Tanaka and Masahito Shimizu

Received: 22 September 2016; Accepted: 16 November 2016; Published: 23 November 2016

\begin{abstract}
Since the observation of Virchow, it has long been known that the tumor microenvironment constitutes the soil for the infiltration of inflammatory cells and for the release of inflammatory mediators. Under certain circumstances, inflammation remains unresolved and promotes cancer development. Here, we review some of these indisputable experimental and clinical evidences of cancer related smouldering inflammation. The most common myeloid infiltrate in solid tumors is composed of myeloid-derived suppressor cells (MDSCs) and tumor-associated macrophages (TAMs). These cells promote tumor growth by several mechanisms, including their inherent immunosuppressive activity, promotion of neoangiogenesis, mediation of epithelial-mesenchymal transition and alteration of cellular metabolism. The pro-tumoral functions of TAMs and MDSCs are further enhanced by their cross-talk offering a myriad of potential anti-cancer therapeutic targets. We highlight these main pro-tumoral mechanisms of myeloid cells and give a general overview of their phenotypical and functional diversity, offering examples of possible therapeutic targets. Pharmacological targeting of inflammatory cells and molecular mediators may result in therapies improving patient condition and prognosis. Here, we review experimental and clinical findings on cancer-related inflammation with a major focus on creating an inventory of current small molecule-based therapeutic interventions targeting cancer-related inflammatory cells: TAMs and MDSCs.
\end{abstract}

Keywords: tumor-associated macrophages; myeloid-derived suppressor cells; inflammatory tumor microenvironment

\section{Introduction}

In the first part of our review we summarize the current knowledge of the role of tumor-infiltrating immune cells in tumor pathogenesis. Briefly, while immune surveillance may eliminate malignant cells, thus preventing tumor formation in the early stage, in late stage cancers, several components of the immune system may promote, rather than suppress tumor growth. In the second part of the review we point out that, intentionally or unintentionally, many anti-tumor drugs target tumor-promoting myeloid-derived suppressor cells (MDSCs) and tumor-associated macrophages (TAMs). We also provide an extensive, although not exhaustive, list of these small molecule-based therapeutic agents and their targets. Synthesizing these data, rational strategies can be proposed for identifying new tumor therapies that more specifically target, eliminate or re-educate, tumor promoting myeloid and lymphoid cells. 


\section{Linking Inflammation and Cancer}

Since the observation of Virchow in 1863, it has long been known that the tumor microenvironment constitutes the soil for the infiltration of inflammatory cells and for the release of inflammatory mediators [1]. Although the coordination of both innate and adaptive immune infiltrate with inflammatory mediators are rendered to serve the elimination of microbial invaders or malignant cells in concert with tissue repair and remodeling, under certain circumstances inflammation remains unresolved and smouldering which promotes cancer development. Now, it is estimated that due to unresolved inflammation $15 \%-20 \%$ of cancer deaths are related to chronic inflammation worldwide [2]. In a seminal study, Hanahan and Weinberg identified six hallmarks of cancer [3]. Due to the fact that inflammatory mediators can cause genetic instability, Mantovani and his colleagues proposed that cancer-related inflammation represents the seventh hallmark of cancer [4]. After a renewal of the seminal paper of Hanahan and Weinberg tumor promoting inflammation as a key hallmark was added to the complexity of cancer [5].

Inflammation sharing signal transduction networks of malignant transformations may arise from genetic defects and alterations in neoplastic cells as an intrinsic pathway [6]. On the other hand, inflammation predisposing for cancer can be driven extrinsically by infections (Helicobacter pylori, hepatitis) [7,8], autoimmune diseases (Crohn's disease, ulcerative colitis) [9], chronic exposure to irritants (asbestos) $[10,11]$ or by multiplex factors like in the case of prostatitis influenced by bacteria, diet and physical trauma to glandular epithelium by corpora amylacea and calculi [12].

In line with the above statements, several molecular evidences link unresolved inflammation and cancer. Here, we highlight molecular evidences of inflammation-driven cancer development or progression. Inflammatory mediators such as IL-1 $\beta$ promote angiogenesis [13] and overexpression of IL-1 $\beta$ mobilized myeloid-derived suppressor cells and induced gastric inflammation associated cancer [14]. IL-1 $\beta$ and TNF- $\alpha$ may alter stromal cells enhancing the expression of CCL2, CXCL8, and CCL 5 by cancer-associated fibroblast and mesenchymal stem cells in the inflammatory tumor microenvironment of breast cancer [15]. TNF- $\alpha$ and IL-6 produced by the immune infiltrate and tumor cells are also considered as master switches between inflammation and cancer sustaining cellular transformation, survival, proliferation, angiogenesis, and metastasis [16,17]. IL-10 is considered as another arm of inflammation associated cancer since both mice and humans deficient in IL-10 developed malignancy $[18,19]$, IL-10 was required for the physiological protective, anti-inflammatory effects of CD4+ CD25+ regulatory lymphocytes to interrupt colon carcinogenesis in mice [20]. The micro RNA, miR-155 may represent another molecular link between inflammation and cancer since elevated miR-155 level of inflammatory cells correlated with malignancy [21]. Carlo M. Croce and his colleagues reported that miR-155 down-regulated core mismatch repair proteins and increased the spontaneous mutation rate [22,23]. Under inflammatory conditions, reactive oxygen (ROS) and reactive nitrogen species (RNS) are released from macrophages, neutrophils and epithelial cells which could cause 8-nitroguanin mutagenic DNA lesions [24,25], moreover it was shown that myeloperoxidase catalyzed formation of hypochlorous acid $(\mathrm{HOCl})$ was responsible for neutrophil induced genotoxicity in lung cancer [26]. Besides direct mutagenic roles of ROS or ROS-related molecular species, ROS as a signaling molecule can influence the expression of several cancer-related genes, including those affecting cell survival, angiogenesis, altered metabolism [27], and has great impact on T-cell immune response in cancer microenvironment [28].

Lifestyle has a great impact on human health. Due to adipose inflammation and metabolic dysfunction excess body weight contributes to obesity-related higher cancer incidence and mortality causing $14 \%$ and $20 \%$ cancer deaths in obese men and women above 50 years, respectively [29]. Reinforces the link between inflammation and cancer that pharmacological targeting of inflammatory cells and molecular mediators may establish therapies improving patient condition and prognosis. Long term use of non-steroid anti-inflammatory drugs (NSAID) as analgesics and antipyretics which are mostly nonselective cyclooxygenase inhibitors reduced incidence and mortality among others in esophageal adenocarcinoma, colorectal and stomach cancer [30,31]. 
The most common myeloid infiltrate in solid tumors is composed by myeloid-derived suppressor cells (MDSCs) and tumor-associated macrophages (TAMs). TAMs represent the major infiltrate of leukocytes in the tumor, a population of alternatively activated M2-like macrophages endowed with pro-tumoral functions such as: immunosuppression, promoting angiogenesis and cancer cell dissemination [32]. While classically activated, M1-like macrophages are pro-inflammatory (IL-12 ${ }^{\text {high }}$, TNF- $\left.\alpha^{\text {high }}\right)$, phagocytic (MHCII ${ }^{\text {high }}$ ) and immunostimulatory expressing co-stimulatory molecules (CD40, CD80, CD86) and recruiting Th1 cells, M2 macrophages play a role in the resolution of inflammation, express anti-inflammatory molecules (IL-10, TGF- $\beta$, IL-1Ra), scavenger (CD163) and C-type lectin (CD206, CD301, dectin-1) receptors, recruit Th2 and regulatory T-cells (T-regs) [33]. MDSCs are CD11b+ and Gr1+ heterogeneous populations of immature myeloid cells developed from bone marrow common myeloid progenitors [34], MDSCs are precursors of granulocytes, monocytes, macrophages and dendritic cells. MDSCs are classified as Ly6C+ monocytic (M-MDSC) and Ly6G+ granulocytic (G-MDSC) subpopulations in mice [35]. Due to the lack of Gr1 homologue in humans the identification of MDSCs is not so evident, human MDSCs consist of phenotypically more heterogeneous population of myeloid cell precursors, briefly M-MDSC (CD11b+, HLA-DR ${ }^{-/ 10 w}, \mathrm{CD} 33+, \mathrm{CD} 14+$, $\left.\mathrm{CD}^{-}{ }^{-}\right)$, G-MDSC $\left(\mathrm{CD} 11 \mathrm{~b}+, \mathrm{HLA}-\mathrm{DR}{ }^{-/ \text {low }}, \mathrm{CD} 33+, \mathrm{CD} 15+\right.$ or $\left.\mathrm{CD} 66 \mathrm{~b}+\right)$ or the less well defined more immature MDSCs (CD14 ${ }^{-}, \mathrm{CD}^{-}$) [36,37]. These cells promote tumor growth by several mechanisms including their inherent immunosuppressive activity, promotion of neoangiogenesis, mediation of epithelial-mesenchymal transition and altering cancer cell metabolism. The pro-tumoral functions of TAMs and MDSCs are further enhanced by their cross-talk offering a myriad of potential anti-cancer therapeutic targets. Since TAMs and MDSCs among the cellular and molecular stromal constituents in the tumor microenvironment shape anti-tumor immunity and could be responsible for chemoresistance [38] we highlight the main pro-tumoral mechanisms of myeloid cells without a plenitude to give a general overview about their phenotypical and functional diversity representing examples of possible therapeutic targets. Our major focus is on the detailed review of small molecule-based therapeutic concepts targeting TAMs and MDSCs. Overall phenotypical and functional description of TAMs and MDSCs is reviewed elsewhere [39-42].

\section{Pro-Tumoral Functions and Mediators of Inflammatory Myeloid Cells, as Potential Therapeutic Targets}

\subsection{Immunosuppression}

TAMs and MDSCs promote immune escape inhibiting both adaptive and innate immunity through a variety of diverse mechanisms paralleled by declined T-cell functions with higher intensity in elderly $[43,44]$. Mainly G-MDSCs accumulate in peripheral lymphoid organs where they possess potent antigen specific suppressive activity, in contrast MDSCs are represented mainly by M-MDSCs in the tumor where they exert non antigen specific suppression and they rapidly differentiate toward TAMs [34]. Granulocytic MDSCs-derived ROS act in cell-cell contact manner, while monocytic MDSCs produce RNS and act through soluble mediators [45,46]. These radicals disrupt T cell receptor (TCR), IL-2 receptor signaling and MHC-TCR interactions [47,48]. MDSCs deplete arginine and cysteine, which are required for T-cell activation and proliferation. In addition, they secrete IL-10 and TGF- $\beta$, which down-regulate the Th1 driving cytokine IL-12 in macrophages [35]. MDSC-derived IL-10 and VEGF-A inhibit dendritic cell maturation. MDSCs promote the expansion and recruitment of both natural and induced T-regs, which further skew the tumor specific immune response into tolerance $[43,48,49]$. Human CD14+ peripheral monocytes can acquire MDSC-like phenotype suppressing autologous T-cell activation and IFN- $\gamma$ production by melanoma produced cyclooxigenase-2 (COX-2) [50]. Subpopulations of MDSCs can give rise to $\mathrm{CD} 11 \mathrm{~b}+\mathrm{F} 4 / 80+$ macrophages with potent immunosuppressive properties [51]. Low oxygen supply via hypoxia-inducible factor- $1 \alpha$ (HIF1- $\alpha)$ promotes MDSC differentiation into TAM in the tumor microenvironment [52]. 
In established tumors MDSC-, T-reg- or TAM-derived IL-10, found in high concentration in the tumor microenvironment, stimulate TAMs to convey inhibitory signals to T-cells through the expression of B7-H1 (PD-L1) [53] and B7-H4 [54]. It has been shown in renal cell carcinoma that TAMs produce substantial amount of CCL2 and immunosuppressive IL-10, in a 15-lipoxygenase-2-dependent way. TAMs also induce the pivotal regulatory T-cell transcription factor FOXP3 and the inhibitory cytotoxic T-lymphocyte antigen 4 (CTLA4) in T-cells, mediating immune tolerance [55]. TAMs further dampen tumoricidal CD8+ cytotoxic T-cell activation by arginase-1 (ArgI) which converts arginin to ornitin, leading to depletion of the key T-cell metabolite L-arginin [56]. TAMs display low MHCII expression, with poor antigen presenting capacity [57]. Myeloid cell specific ablation of adenosine $\mathrm{A}_{2 \mathrm{~A}}$ receptor resulted in reduced melanoma tumor growth with significant increase in MHCII and IL-12 expression in TAMs with concomitant reduction of IL-10 expression in TAMs and MDCSs [58]. It has been reported that tissue resident alveolar macrophages underwent C5a dependent proliferation in a murine breast cancer model, these alveolar macrophages dampened tumor specific Th1 response and prevented the maturation of dendritic cells [59]. In a seminal study of Bronte and his colleagues it was reported that the peripheral tolerance to tumor antigens occurs in the spleen where CD11b+ Gr $1^{\text {int }}$ Ly6 $\mathrm{C}^{\text {high }}$ myeloid cells expand and tolarize memory CD8+ T-cells [60]. In a recent report pancreatic adenocarcinoma up-regulated factor (PAUF) not only enhanced the accumulation of MDSCs in the spleen but also increased the immunosuppressive phenotype of MDSCs by TLR4 dependent upregulation of arginase, nitric oxide (NO) and ROS [61]. Accumulating evidence supports that tumor or tumor stroma-derived free or microvesicle wrapped soluble mediators (IL-10, indolamine-2,3-deoxigenase, ROS, ArgI, $\mathrm{PGE}_{2}$ ) and even cell junction proximity with myeloid cells endow TAMs and MDSCSs with immunosuppressive phenotype dampening both innate and adaptive tumor cell clearance $[44,62,63]$.

\subsection{Angiogenesis}

Most solid tumors remain dormant up to $1 \mathrm{~mm}^{3}$ volume even for decades. Their progression depends on sequential events like the angiogenic switch, an essential step in tumor progression to malignancy [64]. Tumor infiltrating myeloid cells are armed with an arsenal of angiogenic factors, which potentiate tumor invasiveness through the initiation of new blood or lymphatic vessels [43]. In a pioneer study it was proven that the angiogenic switch leading to new tumor vasculature was highly dependent on TAMs, as their genetic depletion diminished angiogenesis in PyMT oncogene driven breast cancer model [65]. In addition, the analysis of human specimens revealed a strong correlation between CD163 TAM infiltration and microvessel density in endometrioid carcinoma [66].

It has been reported that tumor or tumor stroma-derived G-CSF induced Bv8 expression in CD11b+ Gr1+ cells, which enhanced myeloid cell expansion in blood and tumors and increased tumor angiogenesis. Evidence suggests that blocking of Bv8 reduced myeloid infiltrate, angiogenesis and consequently tumor growth [67]. Melanoma derived CSF-1 stimulated macrophages to produce VEGF-A [68]. In renal cell carcinoma, VEGF level, microvessel density and high TAM infiltration have poor prognostic values, associated with high disease recurrence [69]. Amplification of inflammation, when LDL receptor-related protein (LRP1) was deleted in myeloid lineage cells, an increase in TAM density contributed to increased amount of VEGF and consequently higher vascularization in the microenvironment of pancreatic carcinoma [70]. Melanoma conditioned TAMs to produce adrenomedullin (ADM), which in turn mediated angiogenesis by both paracrine (endothelial nitric oxide synthase signaling) and autocrine (M2 polarization of TAMs) effects [71]. Semaphorin 4D (Sema4D) was also reported to be responsible for TAM mediated angiogenesis in a murine breast cancer model. Sema4D production in TAMs is activated by hypoxia (HIF1- $\alpha$ ) and exerts its activity on endothelial cells through its receptor, plexin B1, activating the c-Met tyrosine kinase that promotes the production of a series of cytokines and proteases involved in angiogenesis and subsequent metastasis [72]. An elegant study added new molecular players to the complexity of TAM-mediated angiogenesis. Kale et al. delineated a model in which unknown soluble mediators from melanoma 
cells induced osteopontin (OPN) production by TAMs. Binding of autocrine OPN to the $\alpha 9 \beta 1$ integrin activated TAMs to produce more PGE $_{2}$ and also augmented MMP-9 expression, to effectively regulate melanoma growth through angiogenesis and metastasis [73]. Furthermore, Wnt signaling plays an important role mediating TAM functions, especially in the context of tumor invasion and angiogenesis via TAM derived Wnt7b [74]. In a chick chorioallantoic membrane assay multiple myeloma derived G-MDSC exerted potent pro-angiogenic effect via up-regulation of a series of angiogenic factors, among others angiopoietin-1, angiopoietin-3, leptin, CCL3, PD-ECGF, and TIMP-4 [75].

The Tie-2 angiopoetin-2 receptor expressing monocytes (TEMs) represent the main monocyte population in tumors distinct from TAMs, with a profound angiogenic effect [76]. Angiopoetin-2 is released by tumor associated endothelia cells and is a potent chemoattractant for TEMs. Hypoxia upregulates both Tie-2 and angiopoetin-2 expression leading to the accumulation of TEMs [77].

\subsection{Epithelial-Mesenchymal Transition (EMT), Matrix Remodeling, Metastasis}

Epithelial-mesenchymal transition (EMT) refers to a functional and morphological change when an epithelial cell loses proximal adhesions, cell-cell junctions and acquires mesenchymal motile phenotype. Although EMT is a key process in tissue development and regeneration lots of data accumulated in the last decade about how under pathological circumstances EMT may contributes to malignancy during cancer microevolution. However, the role of EMT in cancer is not fully understood [78]. It has long been known that tumor infiltrating myeloid cells contribute to cancer dissemination causing fatal metastatic disease. In a spontaneous murine melanoma model CCL5 attracted MDSCs to the tumor where MDSCs promoted cancer cell dissemination by induction of EMT via TGF- $\beta$, EGF and HGF pathways [79]. It has been published that TAMs facilitated the EMT of pancreatic cancer cells, by upregulating the mesenchymal markers like vimentin, snail and inhibiting the epithelial marker E-cadherin [80]. Tumor induced MDSCs facilitated nasopharyngeal carcinoma lung metastases via induction of EMT in carcinoma cells via cell-cell contact. TGF- $\beta$ and iNOS enhanced tumor COX-2 expression which activated the $\beta$-catenin/TCF4 pathway resulting in EMT in carcinoma cells [81]. In breast cancer model EMT triggered the release of soluble mediators (IL-6, IL-8, sICAM, PAI-1 and GM-CSF) which induced angiogenesis and recruited MDSCs which might favour cancer spread [82]. However, according to other groups EMT is not required for metastasis rather is responsible for chemoresistance of tumor cells $[83,84]$. Nevertheless, EMT contributes to the intra-tumor heterogeneity by promoting the stemness of cancer cells [85]. Cancer stem cells (CSCs) are a drug-resistant, low immunogenic highly hidden subpopulation within a solid tumor, moreover these CSCs are highly tumorigenic and invasive [85]. In an ovarian carcinoma model MDSCs triggered miR-101 expression in cancer cells, subsequently miR-101 silenced corepressor gene C-terminal binding protein-2 (CtBP2) which resulted in increased cancer stemness and dissemination [86]. Another microRNA, miR-126a released in exosomes of doxorubicin treated MDSCs promoted breast tumor lung metastasis through the induction of IL-13+ Th2 cells [87].

Hagemann et al. reported that co-culture of macrophages and tumor cells caused TNF- $\alpha$-dependent activation of both JNKII and p65 NB- $\mathrm{kB}$, which induced expression of extracellular matrix metalloprotease inducer (EMMPRIN) and macrophage migration inhibitory factor (MIF) in malignant cells, which further increased MMP secretion of macrophages [88]. A similar experimental concept led to the finding that macrophage-derived Wnt 5 can activate AP-1/c-Jun in breast cancer cells, increasing their MMP-7 production [89]. In another study, macrophage-conditioned medium induced EMT and the invasiveness of hepatocarcinoma cells, which was dependent on c-Src-mediated induction of $\beta$-catenin phosphorylation, leading to destabilization of adherent junctions [90]. TAMs induced tumor cell migration and invasiveness also by Cox-2-dependent release of MMP-9 in human basal cell carcinoma [91].

Tissue resident macrophages of the liver, the Kupffer cells had a bimodal effect on colorectal cancer liver metastasis. Depletion of Kupffer cells before tumor induction resulted in increased tumor burden whereas late stage depletion of Kupffer cells decreased VEGF expressing infiltrates and increased 
CD3+ T-lymphocytes consequently diminishing liver tumor load [92]. A more detailed review about the metastatic effect of immune infiltrate has been extensively covered in other publications $[93,94]$.

\subsection{Altered Metabolism}

Metabolic adaptation is a key phenomenon not only in tumor cells but also in the tumor stroma components. Hypoxia forces cells to shift their metabolism towards glycolysis, via upregulation of HIF- $1 \alpha$ dependent genes, including the pyruvate kinase isoenzyme type M2, to produce ATP regardless the oxygen availability ('Warburg effect') [95]. Surprisingly IFN- $\gamma$ and / or LPS activated M1 macrophages display an increased glycolytic flux, rapidly providing the energy required for their functions. In contrast, M2 macrophages exhibit enhanced fatty-acid oxidation and oxidative phosphorylation, with lower rate of glycolysis, sustaining their long-term activities [96]. In IL-4 polarized macrophages Signal Transducer and Activator of Transcription-6 (STAT6) induces the peroxisome proliferator-activated receptor gamma coactivator 1-beta (PGC-1 $\beta$ ) transcriptional co-activator, which further promotes M2 polarization by induction of ArgI and enzymes involved in fatty-acid oxidation and mitochondrial oxidative phosphorylation [97]. During M2 polarization, the $\mathrm{NAD}^{+}$-dependent deacetylase Sirtuin- 1 activates PGC- $1 \beta$ and inactivates p65 NF- $\mathrm{kB}$, thus promoting the shift toward oxidative metabolism and alternative phenotype. TLR4 activation induces the Nicotinamide phosphoribosyltransferase (NAMPT) enzyme which produces $\mathrm{NAD}^{+}$, causing a negative feedback on macrophage activation [96,98]. Although both glycolytic and oxidative consumption rate were higher in tumor MDSCs compared to splenic MDSCs [34], Hossain et al. reported that tumor induced MDSCs increase fatty acid uptake and activate fatty acid oxidation as main metabolic programs [99]. Due to high glycolytic activity tumor cells enhance lactate production by elevated lactate dehydrogenase-A (LDH-A) expression. It has been shown that tumor cell specific LDH-A knockdown resulted in smaller tumors, decreased frequency of MDSCs accompanied with increased NK cytolytic function of NK cells in Pan02 pancreatic cancer model [100].

Epidemiologic studies have been published about the anti-cancer effects of polyunsaturated fatty acids (PUFAs) [101], on the other hand other reports link PUFAs with cancer risk and progression [102]. This discrepancy may rely on the difficulties to record dietary data accurately and also may rely on genetic variations in host PUFA metabolism [102]. Recently, we have showed the radiosensitizing role of PUFAs in human glioma cells [103]. It has been reported that PUFAs promote the expansion of MDSCs in the bone marrow, spleen and blood by activating the Janus kinase/Signal Transducer and Activator of Transcription-3 (JAK/STAT3) signaling. PUFA treatment augmented the T-cell suppressive function of MDSCs which was dependent on increased NADPH oxidase p47phox and consequently elevated ROS production [104].

Macrophages play an important role in the clearance of senescent erythrocytes and the recycling of iron from hemoglobin. Alternatively activated macrophages upregulate the hemoglobin scavenger receptor CD163 (heme uptake) and the iron exporter Ferroportin [105], while classically activated macrophages favor iron retention by high Ferritin (iron storage) and low expression of CD163 and Ferroportin [106]. Thus, M2 macrophages are programmed for iron export to support tissue remodeling and proliferation, while M1 macrophages express bacteriostatic and tumoricidal activity [107].

MDSCs deplete amino acids essential for T-cell survival and functions (e.g., arginine) or tumor induced oxidative metabolism of MDSCs produce reactive oxygen species (e.g., $\mathrm{H}_{2} \mathrm{O}_{2}$ ) or reactive nitrogen intermediates (e.g., peroxinitrit, NO) [108]. However, we do not know much about their other metabolic programs other than the above mentioned immunosuppressive functions linked to metabolic activity of MDSCs [109].

\section{Therapeutic Interventions Targeting TAMs and MDSCs, Tuning the Balance}

Almost half of poorly-differentiated and 95\% of anaplastic thyroid cancer cases showed high TAM infiltration, which correlated with poor survival rate [110]. Lymph node specimens of classic Hodgkin's lymphoma showed high CD68+ macrophage infiltrate and gene expression profiling revealed a gene 
signature of TAMs associated with primary treatment failure and shortened survival [111]. In Ewing sarcoma patients, higher levels of CD68+ macrophages stimulating angiogenesis and osteoclastogenesis were associated with poorer overall survival [112]. In lung adenocarcinoma the majority of TAMs showed M2 polarization accompanied by more aggressive progression, lymphangiogenesis and lymph node metastasis [113]. In diffuse large B-cell lymphoma high CD68+ macrophage infiltration correlated with poor treatment outcome [114], and according to a meta-analysis the high density of TAMs was associated with worse overall survival in patients of breast, bladder, ovarian, gastric, and urogenital cancer [115]. Although there are reports about the positive effects of TAMs in colorectal cancer (CRC) [116,117], it was also shown that intra-tumoral TAMs in CRC correlated with depth invasion, lymph node metastasis and disease progression [118]. Another myeloid populations of tumor promoting cells are immature myeloid precursors, M-MDSCs and G-MDSCs. Several studies reported an elevated level of MDSCs in the blood of human cancer patients in melanoma, prostate cancer, bladder cancer, hepatocellular carcinoma (HCC), non-small cell lung cancer (NSCLC), chronic lymphocytic leukaemia (CLL), esophageal squamous cell carcinoma (ESCC), Hodgkin lymphoma, renal cell carcinoma (RCC), and in head and neck squamous cell carcinoma (HNSCC) [37]. Increased MDSC percentage was associated with higher risk of death in pancreatic, esophageal, gastric cancer and melanoma $[119,120]$.

As a body of evidence from human clinical studies suggests how TAMs and MDSCs may facilitate tumor progression, novel therapies directed against myeloid infiltrate are emerging both in the clinic and preclinical research. Possible therapeutic approaches include: (a) inhibiting the recruitment and/or proliferation of monocytes/macrophages; (b) their selective ablation or (c) re-education to tumoricidal rather than tumor promoting functions; (d) differentiate immature myeloid cells or (e) pharmacologically inhibit their mediators responsible for pro-tumoral functions. Remarkably, modulation of MDSC and macrophage function is frequently an off-target effect of diverse drugs originally designed for other therapies.

\subsection{Inhibition of the Recruitment and/or Proliferation of Tumor-Associated Macrophages (TAMs) and Myeloid-Derived Suppressor Cells (MDSCs)}

Chemokines are key agents that attract macrophages to tumors. Inhibition of the monocyte chemoattractant protein MCP-1 (CCL2) with bindarit resulted in reduced tumor growth in human melanoma xenografts [121]. Bindarit enhanced expression of the NF- $\kappa B$ inhibitor IKB- $\alpha$, modulating cancer cell proliferation in vitro and caused the impairment of tumor growth and metastasis formation with reduction in myeloid cell infiltration, in animal models of prostate and breast cancer [122]. Surprisingly anti-CCL2 monoclonal antibody treatment did not affect TAM recruitment but polarized TAMs to a more antitumor phenotype, where the tumor regression was CD8+ T-cell dependent in a murine NSCLC cancer model [123] (Table 1).

Macrophage colony stimulating factor M-CSF (CSF-1) is a potent monocyte/macrophage growth factor. Radiotherapy induced TAM and MDSC expansion in prostate cancer patients with an increase in M-CSF serum level. Mechanistic studies revealed that DNA damage-induced kinase ABL1 enhanced CSF-1 expression, while selective inhibition of its receptor kinase CSF1R (CD115) by GW2850 or PLX3397 inhibitors hampered TAM recruitment and suppressed tumor growth in murine prostate [124] and thyroid [125] cancer models. Moreover, blockade of CSF1/CSF1R signaling by GW2850 and PLX3397 CSF1R inhibitors or by anti-CSF-1 not only blocked TAM and M-MDSC recruitment, but also killed CD206 $6^{\text {high }}$ TAMs and reprogrammed the remaining TAMs to support anti-tumor immune activities in murine ductal pancreatic adenocarcinoma [126]. When anti-CSF1 treatment was combined with anti-PD-1/anti-CTLA4 immunotherapy with gemcitabine chemotherapy they observed complete tumor regression in $30 \%$ of mice and an average tumor regression of $85 \%$ [126]. We showed that during cancer-driven granulo-monocytopoiesis colony stimulating factors (CSFs: G-CSF, GM-CSF, M-CSF) stimulate the expansion and recruitment of tumor promoting myeloid cells wherein retinoic-acid-related orphan receptor 1 (RORC1) drives cancer-related myelopoiesis in 
response to CSFs, antagonizing CSFs prevented cancer driven-myelopoiesis or the ablation of RORC1 hampered generation of TAMs and MDSCs in line with reduced MN/MCA1 tumor growth and lung metastasis [127] (Table 1).

Treatment of Ma-Mel-51 human melanoma cells by vemurafenib, a selective inhibitor of B-Raf kinase inhibited the release of soluble factors to generate M-MDSCs in vitro. Moreover, vemurafenib blocked the ability of malignant cells to recruit both M-MDSC and ArgI+ G-MDSCs in the blood of patients with advanced melanoma [128] (Table 1).

Table 1. Chemical agents for the inhibition of the recruitment and/or proliferation of myeloid-derived suppressor cells (MDSCs) and tumor-associated macrophages (TAMs).

[121,122]
In Vivo Effect

\subsection{Selective Ablation, Depletion of TAMs and MDSCs}

Removal of unwanted alternatively activated macrophages and immature myeloid cells offers a promising therapy. Anti-CD115 monoclonal antibody treatment successfully reduced tumor growth and prolonged survival of mice due to depletion of F4/80+ TAMs in the MMTV-PyMT murine breast cancer model $[129,130]$. Zoledronic acid (ZA) a bisphosphonate is used to treat bone damage in cancer patients, but it also has been reported to reduce the percentage of TAMs and to revert their polarization from M2 to M1 [131,132]. Selective ablation of TAMs using a tumor microenvironment-activated, legumain sensitive doxorubicin-based prodrug LEG-3, depleted TAMs, decreased circulating tumor cells and MDSCs in the spleen, with inhibition of breast tumor growth and metastasis formation $[133,134]$. Similar results were achieved using clodronate encapsulated liposomes for selective depletion of macrophages in human melanoma xenografts and in dogs with soft-tissue sarcoma $[121,135]$. A licensed and commercially available anticancer agent, trabectedin (Yondelis ${ }^{\circledR}$ ), induced apoptosis in mononuclear phagocytes (TAMs, monocytes), in a caspase-8 dependent manner, leading to less tumor growth and angiogenesis [136,137] (Table 2).

It has been reported the nucleoside analog, conventional chemotherapeutical agent gemcitabine caused apoptosis and necrosis of splenocytes, selectively reduced the expansion of Gr1+/CD11b+ 
splenic MDSCs preserving CD4+ and CD8+ T-cells and that was accompanied by augmented antitumor activity of CD8+ T-cells and enhanced IFN- $\beta$ gene delivery in murine mesothelioma [138]. In the 4T1 murine breast carcinoma early gemcitabine treatment also decreased MDSCs and improved T-cell proliferation and IFN- $\gamma$ response [139]. A recently published new approach, lipid nanocapsules loaded with a lauroyl modified form of gemcitabine enhanced therapeutic efficacy, reduced tumor infiltrating and splenic M-MDSCs, attenuated tumor-associated immunosuppression in murine lymphoma and melanoma models [140]. Another classic chemotherapeutic agent, the pyrimidine analog 5-fluorouracil (5-FU) also has been shown to cause apoptosis and depletion of MDSCs with stronger efficacy over gemcitabine. Depletion of MDSCs by 5 -FU promoted IFN- $\gamma$ production and anti-tumor response without significant effect on dendritic cells, T-cells, B-cells and NK cells [141]. Bruchard et al. reported that gemcitabine and 5-FU induced not simply apoptosis of MDSCs but also the activation of the Nlrp3 inflammasome leading to the secretion of the inflammatory cytokine IL-1 $\beta$ and consequently the production of CD4+ T-cell-derived, tumor growth promoting IL-17. In line with this gemcitabine and 5-FU treatment should be combined with the inhibitors of Nlrp3 or IL-1 $\beta$ signaling [142]. Wang et al. recently published that MDSC depleting chemoterapeutics (gemcitabine and 5-FU) combined with adoptive immunotherapy using cytokine induced killer cell therapy increased 1-year survival rates of metastatic renal cell carcinoma and advanced pancreatic cancer patients [143]. Cisplatin a traditional chemotherapeutic agent depleted $50 \%$ of tumor infiltrating Gr1+/CD11b+ MDSCs without the impairment of $\mathrm{T}$ and $\mathrm{B}$ cell subsets, additionally cisplatin abrogated the immunosuppressive phenotype of the rest myeloid infiltrate in B16 melanoma model [144]. SAR131675, the inhibitor of VEGFR-3 exerted anti-tumoral activity in murine $4 \mathrm{~T} 1$ model via reduction of the frequency of splenic Gr1+/CD11b+ cells and F4/80 high TAMs [145]. Targeting A20, a zinc-finger protein over-expressed in MDSCs by small interfering RNA resulted in caspase- 3 and caspase- 8 dependent apoptosis of MDSCs and increased tumor specific T-cell response, consequently reduced tumor growth in mice [146]. Myeloid cell depletion is able to enhance vaccine efficacy since immunization with TLR9 and NOD-2 containing microparticles followed by anti-CD11 treatment further delayed tumor progression in a mouse model of epithelial ovarian cancer [147]. Ibrutinib, an irreversible inhibitor of Bruton's tyrosin kinase (BTK) and IL-2 inducible T-cell kinase (ITK) inhibited not only the generation of human MDSCs in vitro but also the recruitment of CD11b+/Gr1 + MDSCs in the tumor and spleen in murine breast cancer and melanoma models. Ibrutinib significantly enhanced the efficacy of the anti-PD-L1 immunotherapy via MDSC depletion which was dependent on BTK inhibition in mice [148] (Table 2).

Sunitinib, a receptor tyrosine kinase inhibitor decreased both HLA-DR ${ }^{-}$CD33+ CD15+ and HLA-DR ${ }^{-}$CD33+ CD15 ${ }^{-}$MDSCs in the blood of renal cell carcinoma patients which was associated with the reversal of Th1 response by enhanced production of T-cell IFN- $\gamma$ and reduction in CD3+ CD4+ CD25 high Foxp3+ T-regs [149]. In another recent study sunitinib reduced non-classical CD33+ CD14+ CD16+ MDSCs in the blood of cancer patients by apoptosis and the rest of CD33+ CD14+ CD16+ MDSCs showed less pSTAT3, ArgI and less suppressive activity on T-cell proliferation. Moreover, sunitinib responders showed decreased T-reg population and sunitinib synergized with radiotherapy improving patient progression-free survival [150]. Administration of sunitinib in combination with immunotherapy (a viral vector based cancer vaccine) with or without irradiation could further increase its antitumoral activity via depleting circulating and intra-tumoral MDSCs and elevation of the level of antigen specific cytotoxic T lymphocytes in mice [151,152] (Table 2). 
Table 2. Chemical agents for the selective ablation, depletion of TAMs and MDSCs.

\begin{tabular}{|c|c|c|c|c|}
\hline Compounds & Chemical Structures & In Vivo Effect & $\begin{array}{l}\text { Mechanism } \\
\text { of Action }\end{array}$ & References \\
\hline Zoledronic acid & $\begin{array}{l}\mathrm{HO} \text { 、 } \\
\mathrm{HO}^{\prime}\end{array}$ & $\begin{array}{l}\text { Reduced the } \\
\text { number of TAMs } \\
\text { and reverted their } \\
\text { polarization from } \\
\text { M2 to M1 }\end{array}$ & $\begin{array}{l}\text { Inhibits the active } \\
\text { site of the enzyme } \\
\text { farnesyl } \\
\text { pyrophosphate } \\
\text { (FPP) synthase in } \\
\text { the mevalonate } \\
\text { (Mev) pathway }\end{array}$ & {$[131,132]$} \\
\hline $\begin{array}{l}\text { Doxorubicin-based } \\
\text { prodrug (LEG-3) }\end{array}$ & & Depletes TAMs & $\begin{array}{l}\text { LEG-3 is a } \\
\text { legumain, an } \\
\text { asparagynil } \\
\text { endopeptidase } \\
\text { activated prodrug. } \\
\text { Doxorubicin is a } \\
\text { DNA intercalator }\end{array}$ & {$[133,134]$} \\
\hline $\begin{array}{l}\text { Clodronate } \\
\text { (encapsulated } \\
\text { liposomes) }\end{array}$ & & Depletes TAMs & $\begin{array}{l}\text { Clodronate is } \\
\text { converted to } \\
\text { non-hydrolyzable } \\
\text { ATP analogue } \\
\text { intracellularly }\end{array}$ & {$[121,135]$} \\
\hline $\begin{array}{l}\text { Trabectedin } \\
\left(\text { Yondelis }^{\circledR}\right)\end{array}$ & & $\begin{array}{l}\text { Induces apoptosis } \\
\text { of mononuclear } \\
\text { phagocytes (TAMs, } \\
\text { monocytes) }\end{array}$ & $\begin{array}{l}\text { Caspase- } 8 \\
\text { activation via } \\
\text { TRAIL-Rs pathway }\end{array}$ & {$[136,137]$} \\
\hline Gemcitabine & & $\begin{array}{l}\text { Reduces the } \\
\text { expansion of } \\
\text { Gr1+/CD11b+ } \\
\text { splenic MDSCs }\end{array}$ & Nucleoside analog & [139] \\
\hline $\begin{array}{l}\text { 5-fluorouracil } \\
\text { (5-FU) }\end{array}$ & & $\begin{array}{l}\text { Causes apoptosis } \\
\text { and depletion } \\
\text { of MDSCs }\end{array}$ & Pyrimidine analog & [141] \\
\hline Cisplatin & $\mathrm{Cl}^{\mathrm{Cl}}{ }^{\stackrel{\mathrm{Pt}}{\mathrm{NH}_{3}}}$ & $\begin{array}{l}\text { Depleted } 50 \% \text { of } \\
\text { tumor infiltrating } \\
\text { Gr1+/CD11b+ } \\
\text { MDSCs }\end{array}$ & $\begin{array}{l}\text { Forms DNA } \\
\text { adducts }\end{array}$ & [144] \\
\hline SAR131675 & Et & $\begin{array}{l}\text { Reduces the } \\
\text { number of splenic } \\
\text { Gr1+/CD11b+ cells } \\
\text { and F4/80high } \\
\text { TAMs }\end{array}$ & VEGFR-3 inhibitor & [145] \\
\hline
\end{tabular}


Table 2. Cont.

Compounds

\subsection{Re-Education of TAMs and MDSCs to Exert Anti-Tumor Functions}

Re-educating tumor promoting myeloid cells, tuning the balance by alleviating their immunosuppressive effect offer a therapeutic strategy to improve cancer outcome [153]. In vivo IL-12 treatment altered TAM profile, promoting their pro-inflammatory activities from IL- $10^{\text {high }}$, TGF- $\beta^{\text {high }}$ to a TNF- $\alpha^{\text {high }}$ phenotype in a murine lung cancer [154]. It was shown in the IFN- $\alpha / \beta R^{-/-}$ genetic model that endogenously produced type I interferons suppress the generation of TAMs, which indicate local application of IFN $\alpha / \beta$ as a potential therapeutic [155]. Inhibition of p50/p50 NF- $\mathrm{KB}$ nuclear translocation in TAMs [156], and the inhibition of IKK $\beta$ kinase reversed TAM phenotype from pro-tumoral to classically activated tumoricidal: $\mathrm{IL}-12^{\text {high }}$, MHCII ${ }^{\text {high }}$, IL- $10^{\text {low }}$, Arginase- $1^{\text {low }}[156,157]$.

Macrophage migration inhibitory factor (MIF) deficient macrophages showed decreased immunosuppressive and pro-angiogenic gene expression with less tumor burden in mice. Pharmacological targeting of MIF by a small molecule antagonist, 4-iodo-6-phenylpyrimidine (4-IPP) also reduced tumor growth by reduction of ArgI and elevation of TNF- $\alpha$ expression in TAM, furthermore 4-IPP attenuated TAM and both splenic Gr1 ${ }^{\text {high }}$ Ly6G+ G-MDSC and Gr1 ${ }^{\text {dim }}$, Ly6G ${ }^{-}$ M-MDSCs mediated immunosuppression [158]. In a male-predominant hepatocellular carcinoma model, 17 $\beta$-estradiol (E2) repressed alternative macrophage activation and tumor growth through the inhibition of Janus activated kinase-1 (JAK1) and STAT6 phosphorylation [159]. The fact that M2 macrophages express higher legumain (a cysteine protease) on their cell surface allows selective therapy. Legumain targeted nanoparticles encapsulating hydrazinocurcumin suppressed STAT3 and re-educated TAMs, to be IL- $12^{\text {high }}$, IL- $10^{\text {low }}$ and TGF- $\beta^{\text {low }}$, which resulted in suppression of tumor growth, metastasis and angiogenesis in vivo [160]. Several new curcumin derivatives have been synthesized and were confirmed to have anticancer activities, however their potential effects on TAMs and MDSCs would be interesting to test [161]. Another inhibitor of JAK1 and STAT3, a synthetic triterpenoid, bardoxolone methyl (C-28 methyl ester of 2-cyano-3,12-dioxooleana-1,9,-dien-28-oic acid, also known as CDDO-Me) abrogated the immune suppressive effect of MDSCs on CD8+ cytotoxic T-cells resulting in decreased tumor growth in mice [162,163]. 5,6-Dimethylxanthenone-4-acetic-acid (DMXAA, Vadimezan or ASA404) augmented tumor immunotherapy by increasing the infiltration of neutrophils and M1 macrophages in concert with the higher frequency of CD8+ T-cell recruitment to the tumor. The beneficial effect of DMXAA relied on the modulation of macrophages since the clodronate depletion of macrophages markedly alleviated the therapeutic response of DMXAA in mice [164]. Administration of yeast-derived whole $\beta$-glucan particles (WGP), a ligand of C-type lectin dectin-1, decreased tumor growth of Lewis lung carcinoma and E0771 mammary carcinoma in mice. WGP subverted the immunosuppression of both splenic and tumor MDSCs, reduced accumulation of G-MDSC and differentiated M-MDSC into CD11c+ professional antigen presenting cells successfully 
promoting Th1 differentiation and antigen cross-presentation to CD8+ effector cells [165,166]. Inhibitors (sildenafil, tadalafil, vardenafil) of phosphodiestarase-5 (PDE-5) by preventing the hydrolysis of cGMP have been used to treat erectile dysfunction, pulmonary arterial hypertension and cardiac hypertrophy in the clinical practice $[167,168]$. Serafini et al. showed that sildenafil increased cGMP, reduced IL-4R $\alpha$ expression and down-regulated ArgI and NOS2 enzymatic activity of tumor infiltrating MDSCs thereby reduced the immunosuppression of G1+/CD11+ myeloid cells with improving the efficacy of adoptive T-cell therapy in tumor bearing mice [169] (Table 3).

Immunotherapy boosts antigen specific anti-tumor immune response or augments the overall immune response by adjuvant therapy to modulate tumor microenvironment and combat different points of tumor-driven immune-escape mechanisms. Anti-phosphatidylserine antibody (2aG4) in combination with docetaxel inhibited the growth of LNCaP and PC3 human prostate xenograft models in SCID mice via repolarization of M2 TAMs to M1 with higher expression of TNF- $\alpha$, IL-12, MHCII and elevated expression of co-stimulatory CD40, CD80, CD86 molecules. Docetaxel increased phosphatidylserine exposure on tumor vessels which were disrupted by these predominantly M1-like TAMs. Furthermore, 2aG4 decreased the infiltration of Gr1+ cells and differentiated MDSCs toward M1 macrophages and dendritic cells changing the microenvironment to immunostimulatory [170]. In human melanoma patients Ipilimumab (anti-CTLA4) therapy was the first one to improve patient survival at stage III/IV significantly reducing G-MDSC frequency followed by the reduction of ArgI producing $\mathrm{CD}^{-}$cells [171]. Although the frequency of M-MDSCs did not change by Ipilimumab treatment and M-MDSC level linearly correlated with the clinical outcome as a prognostic marker [172], 2-year survival probability after ipilimumab initiation was 34.5\% for 99 patients with Lin $^{-}$CD14+ HLA-DR ${ }^{\text {low }}$ MDSC frequencies $<5.1 \%$, while there were no survivors among 65 patients with higher MDSC levels [173]. Blocking PD-1/PDL-1 immune checkpoint molecules by anti-PD or anti-PD-L1 antibodies in combination with GVAX, FVAX immunotherapy (GM-CSF or FLT3 expressing irradiated tumor cells) alone or followed by a-4-1BB stimulation or TLR9 agonist (CPG 1668) resulted in the rejection of 50\% (GVAX-aPD-1 or FVAX-aPD-1) or 75\% (GVAX-4-1BB-aPD-L1 or FVAX-4-1BB-aPD-L1) of ID8 ovarian carcinoma tumors in mice. Anti-PD-L1 decreased ArgI activity of MDSCs, furthermore GVAX-4-1BB-aPD-L1 or FVAX-4-1BB-aPD-L1 combinatorial immunotherapy restored T-cell immunity with increased IFN- $\gamma$ and TNF- $\alpha$ production in concert with the elevation of T:MDSC cell ratio [174]. Polyclonal and poly-specific intravenous immunoglobulins (IVIgs), prepared from the plasma of thousands of human healthy donors repolarized human M2 macrophages toward M1 via Fc $\gamma$ RIII (CD16) and Syk phosphorylation dependent manner, moreover IVIgs inhibited MC38 colon cancer progression which was dependent on macrophages, FcgRIII, FcgRIV and FcRg-chain [175]. Cationic dextran and polyethyleneimine repolarized MDSCs of 4T1 tumor bearing mice into anti-tumor cells to express tumoricidal cytokines (IL-12, TNF- $\alpha$ ) with less production of immunosuppressive factors (IL-10, TGF- $\beta$ ) reactivating T-cell functions which resulted in reduced tumor growth and prolonged survival [176].

Adjuvants to augment cancer immunotherapy and overcome MDSC mediated immunosuppression provide immunostimulatory signals boosting the immune response via bacterial products or Toll-like receptors, cytokines and growth factors or by immunostimulatory delivery systems (e.g., nanoparticles targeting TAMs to deliver tumor antigens) [177,178]. Toll-like receptor-9 (TLR9) agonist CpG oligonucleotids (ODNs) affected on TLR9 expressing M-MDSC cells. CpG ODNs reduced intra-tumoral M-MDSC infiltration, NO and ArgI production, increased IL-12 expression of splenic M-MDSC losing their ability to suppress CD8+ T-cells. CpG ODNs induced the differentiation of M-MDSCs to F4/80+ macrophages supporting tumor elimination [179]. RNA adjuvant therapy mimicking dsRNA by Poly(I:C) modulated tumor infiltrating myeloid cells via TLR3/TICAM-1 pathway from tumor-supportive to tumor-suppressive [180]. Another adjuvant, co-administration of the TLR7 agonist imiquimod led to improved antitumor effect of cancer vaccine augmenting tumor specific immune response based on the decline of tumor infiltrating MDSCs and on the activation of antitumor NK 1.1+ and F4/80+ macrophages [181]. Tasquinimod, a novel antitumor agent has been reported 
to prolong the progression-free survival of human castration-resistant prostate cancer patients [182]. Tasquinimod enhanced the effectiveness of immunotherapy, inhibited the accumulation of Ly6C+ MDSCs and CD206+ M2-like TAMs via targeting S100A9, furthermore CD11b+ myeloid cells showed less ArgI and iNOS expression which resulted in significantly reduced tumor growth in murine models of prostate cancer and melanoma [183] (Table 3).

Although tumor infiltrating dendritic cells (CD45+ CD11c+ MHCII+) are not macrophages, they may arise from the same monocytic precursors and may share a series of signal transduction pathways leading to alternative activation [184]. These tumor-associated dendritic cells were transformed from immunosuppressive to highly immunostimulatory cells, capable to trigger a potent antitumor immune response by the administration of miR-155 mimetics, which inhibited CEBP/ $\beta$, SOCS1, PU.1 transcription factors, leading to upregulation of TNF- $\alpha$, IL-12 and IFN- $\gamma$ in the tumor microenvironment [185].

Infiltration of myeloid cells to the tumor microenvironment is often associated with increased neoangiogenesis characterized by higher microvessel density in the tumor [186]. Inhibition of PI3K $\gamma$ and $\delta$ in myeloid cells by the small-molecule inhibitor IPI145 enhanced the efficacy of VEGF/VEGFR blockade anti-angiostatic therapy by sorafenib. IPI145 decreased intratumoral TAM, Gr1+ monocytes and tumor-associated neutrophils, moreover IPI145 induced perforin expression of cytotoxic T lymphocytes generating an immune stimulatory tumor microenvironment [187]. Prokineticin 2 (PK2 or Bv8) has been reported to play a role in the mobilization of myeloid cells and in the recruitment of TAMs and neutrophils to the tumor site promoting angiogenesis. A small molecule PK2 antagonist, PKRA7 inhibited tumor growth via interfering neovascularization of glioma and myeloid cell infiltration of pancreatic cancer xenografts, respectively [188] (Table 3).

Based on our current knowledge about the role of infiltrating immune cells in tumor growth, it seems plausible that alternatively activated macrophages might be among the main targets of conventional anti-tumor radiotherapy and chemotherapy as well. Radiotherapy and chemotherapy are known to damage the gut epithelium, facilitating the translocation of bacteria and contact of bacterial danger signals with the circulation $[189,190]$. Gut bacteria or their cell wall components were shown to induce a Type 1 macrophage polarization [191,192]. In addition, chemotherapeutic agents have a well-known immunosuppressive effect; in fact, some anti-tumor compounds, e.g., alkylating agents and antimetabolites, are also used for immunosuppression in transplantation or autoimmunity [193]. Immunosuppression, in turn, may also facilitate opportunistic infections that may lead to M1 type macrophage polarization. In accordance with these data, infections might indeed be associated with spontaneous tumor regression [194]. The hypothesis is further supported by observations that gut flora is crucial for an effective chemotherapy [195].

Table 3. Chemical agents for the re-education of TAMs and MDSCs to exert anti-tumor functions.

\begin{tabular}{|c|c|c|c|c|}
\hline Compounds & Chemical Structures & In Vivo Effect & $\begin{array}{l}\text { Mechanism } \\
\text { of Action }\end{array}$ & References \\
\hline $\begin{array}{l}\text { 4-iodo-6-phenylpyrimidine } \\
\text { (4-IPP) }\end{array}$ & & $\begin{array}{l}\text { Reduces ArgI and } \\
\text { elevates TNF- } \alpha \\
\text { expression in TAM, } \\
\text { attenuates TAM and both } \\
\text { splenic Gr1 }{ }^{\text {high }} \text { Ly6G+ } \\
\text { G-MDSC and Gr1 dim, } \\
\text { Ly6G }{ }^{-} \text {M-MDSCs } \\
\text { mediated } \\
\text { immunosuppression }\end{array}$ & $\begin{array}{l}\text { Migration } \\
\text { inhibitory factor } \\
\text { (MIF) antagonist }\end{array}$ & [158] \\
\hline Hydrazinocurcumin $\quad H$ & & $\begin{array}{l}\text { Re-educates TAMs to be } \\
\text { IL- } 12^{\text {high }}, \text { IL-10 } 10^{\text {low }} \\
\text { and TGF- } \beta^{\text {low }}\end{array}$ & Suppresses STAT3 & [160] \\
\hline
\end{tabular}


Table 3. Cont.

\begin{tabular}{|c|c|c|c|c|}
\hline Compounds & Chemical Structures & In Vivo Effect & $\begin{array}{l}\text { Mechanism } \\
\text { of Action }\end{array}$ & References \\
\hline $\begin{array}{l}\text { Bardoxolone } \\
\text { methyl } \\
\text { (CDDO-Me) }\end{array}$ & & $\begin{array}{l}\text { Abrogates the immune } \\
\text { suppressive effect } \\
\text { of MDSCs }\end{array}$ & $\begin{array}{l}\text { JAK1 and } \\
\text { STAT3 inhibitor }\end{array}$ & {$[162,163,196]$} \\
\hline $\begin{array}{c}5,6 \\
\text { Dimethylxanthenone- } \\
\text { 4-acetic-acid } \\
\text { (DMXAA, } \\
\text { Vadimezan or } \\
\text { ASA404) }\end{array}$ & & $\begin{array}{l}\text { Increases the influx of } \\
\text { neutrophils and } \\
\text { anti-tumour (M1) } \\
\text { macrophages to the } \\
\text { tumour, induces } \\
\text { macrophage activation, } \\
\text { augments the therapeutic } \\
\text { effects of immunotherapy }\end{array}$ & $\begin{array}{l}\text { 'Stimulator of } \\
\text { interferon gene' } \\
\text { (STING) agonist, } \\
\text { multi-kinase } \\
\text { inhibitor }\end{array}$ & {$[164,197]$} \\
\hline Sildenafil $\left(\right.$ Viagra $^{\circledR}$ ) & & $\begin{array}{l}\text { Down-regulates ArgI and } \\
\text { NOS2 enzymatic activity } \\
\text { of tumor } \\
\text { infiltrating MDSCs }\end{array}$ & $\begin{array}{l}\text { Phosphodiesterase-5 } \\
\text { (PDE-5) inhibitor }\end{array}$ & [169] \\
\hline Imiquimod & & $\begin{array}{l}\text { Decreases tumor } \\
\text { infiltrating MDSCs and } \\
\text { activates antitumor NK } \\
1.1+\text { cells and F4/80+ } \\
\text { macrophages in } \\
\text { combination with } \\
\text { immunotherapy }\end{array}$ & TLR7 agonist & {$[177,181]$} \\
\hline Tasquinimod & & $\begin{array}{l}\text { Inhibits the accumulation } \\
\text { of Ly6C+ MDSCs and } \\
\text { CD206+ M2-like TAMs }\end{array}$ & $\begin{array}{l}\text { Orally active } \\
\text { S100A9 inhibitor }\end{array}$ & {$[182,183,198]$} \\
\hline IPI145 (Duvelisib) & & $\begin{array}{l}\text { Enhances the efficacy of } \\
\text { VEGF/VEGFR blockade } \\
\text { anti-angiostatic therapy } \\
\text { by sorafenib. IPI145 } \\
\text { decreases intra-tumoral } \\
\text { TAM, Gr1+ monocytes } \\
\text { and tumor-associated } \\
\text { neutrophils }\end{array}$ & $\begin{array}{l}\text { Phosphatidylinositol-3 } \\
\text { kinase } \gamma \text { and } \delta \\
\text { (PI3K } \gamma \text { and } \delta \text { ) } \\
\text { inhibitor }\end{array}$ & [187] \\
\hline PKRA7 & & $\begin{array}{l}\text { Inhibits the } \\
\text { neovascularization of } \\
\text { glioma and myeloid cell } \\
\text { infiltration of } \\
\text { pancreatic cancer }\end{array}$ & $\begin{array}{l}\text { Prokineticin } 2 \text { (PK2 } \\
\text { or Bv8) antagonist }\end{array}$ & [188] \\
\hline
\end{tabular}

\subsection{Differentiation of MDSCS}

Since MDSCs represent immature myeloid cells with inherent immunosuppressive activity differentiation of MDSCs into mature myeloid cells thereby restoration of T-cell immunity would be a promising therapeutic strategy [196].

It was published quite early that pretreatment with TGF- $\beta$ of human promyelocytic cells followed by 1,25-dihydroxyvitamin D3 (vitamin D3) treatment induced monocytic maturation [199], while in other study vitamin D3 treatment of mice having Lewis lung carcinoma reduced the frequency of myeloid progenitors and tumor-driven myelopoiesis associated immunosuppression leading to transient tumor regression and prominent metastasis reduction [200]. In a human phase 1B clinical 
study 25-dihydroxyvitamin D3 reduced the number of CD34+ immunosuppressive cells, increased HLA-DR expression, elevated plasma IL-12 and IFN- $\gamma$ level in the blood of HNSSC patients [201]. Another vitamin D derivative, all-trans retinoic acid (ATRA) combined with GM-CSF differentiated immature myeloid Gr1+ cells, eliminated their inhibitory potential and restored the number of IFN- $\gamma$ producing cells [202]. ATRA ( $>150 \mathrm{ng} / \mathrm{mL}$ in the blood) dramatically reduced the percentage of immature myeloid suppressive cells in the blood of human metastatic renal cell carcinoma patients and improved antigen specific T-cell response [203]. The TLR7/8 agonist imidazoquinoline-like molecule, resiquimod treated MDSCs differentiated to F4/80+ macrophages and CD11c+/MHCII+ $\left(\mathrm{I}-\mathrm{A}^{\mathrm{d}+}\right)$ dendritic cells exerting potent T-cell stimulatory function [204] (Table 4.).

Table 4. Chemical agents for the differentiation of MDSCs.

Compounds

\subsection{Pharmacological Targeting of the Pro-Tumoral Mediators of TAMs and MDSCs}

Celecoxib a cyclooxigenase II (COX-2) inhibitor reverted TAM phenotype from M2 to M1, associated with reduced intestinal tumor progression [205]. Another COX-2 inhibitor, etodolac blocked M2 macrophage differentiation and suppressed metastasis formation in a murine breast cancer model [206]. MDSC induction from healthy human monocytes and their immunosuppressive phenotype induced by early-passage melanoma cells via cell-cell contact or close proximity was completely abolished by the COX-2 inhibitor celecoxib. Moreover, inhibition of STAT3 phosphorylation by Tyrphostin AG490 in patient-derived CD14+ cells alleviated their T-cell inhibitory function [50] (Table 5).

Many of the immunosuppressive effects of MDSCs rely on the release of ROS. Withaferin A (WA), a component of the root extract of Withania somnifera inhibited ROS production of Gr1+ CD11b+ MDSCs by inhibition of STAT3 phosphorylation, WA also reduced IL-10 production generated by MDSC-macrophage cross-talk. Macrophage secretion of pro-inflammatory cytokines IL- 6 and TNF- $\alpha$, which increase MDSC accumulation, was also reduced by WA, additionally WA delayed tumor progression with reduction of the accumulation of G-MDSCs in 4T1 mammary carcinoma bearing mice [207] (Table 5). 
Table 5. Pharmacological targeting of the pro-tumoral mediators of TAMs and MDSCs.

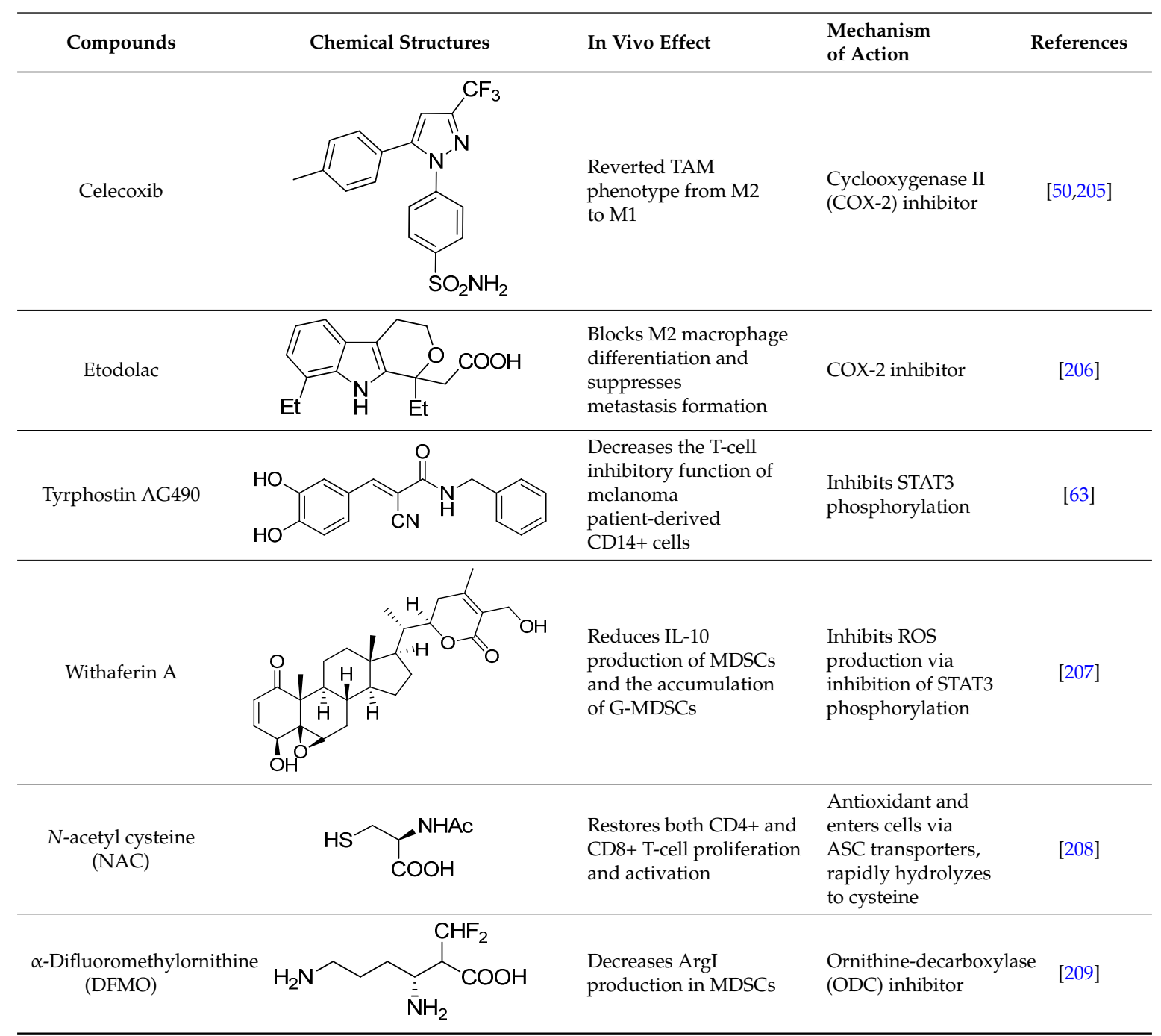

MDSCs inhibit T-cell proliferation not only by arginase, ROS, RNS and IL-10 but also by depleting cysteine. T-cells import cysteine by the ASC neutral amino acid transporter. Both APC cells and MDSCs express $\mathrm{X}_{\mathrm{c}}{ }^{-}$transporter for the uptake of cystine and APC cells export cysteine for T-cells. In contrast, MDSCs compete with APCs for the uptake of cystine and do not export cysteine. Therefore, MDSCs consume cystine and deprive T-cells from cysteine constraining T-cell activation and proliferation. $\mathrm{N}$-acetyl cysteine (NAC) enters cells via ASC transporters, and is hydrolyzed rapidly to cysteine, restoring both CD4+ and CD8+ T-cell proliferation and activation [208] (Table 5).

Another component of amino acid metabolism, ornithine-decarboxylase (ODC) was showed to be a potential therapeutic target which is upregulated in Gr1+/CD11b+ MDSCs of tumor bearing mice. Inhibition of ODC by $\alpha$-difluoromethylornithine (DFMO) decreased ArgI production in MDSCs consequently DFMO treated MDSCs failed to retain their suppressive activity which led to slower tumor growth in wild type mice but not in Rag1-/- immunodeficient mice suggesting that DFMO treatment augments antitumor immunity via modulation of ODC in MDSCs [209] (Table 5).

\section{Conclusions}

We have seen that many of the currently developed anti-cancer therapeutics and traditional chemotherapeutic agents target TAMs and MDSCs (Figure 1), augmenting the anti-tumor immune response and improving patient outcomes. Exploitation of these non-conventional immunomodulating 
effects might require different drug dosage or administration, as compared with those required for the primary indications of the agents.

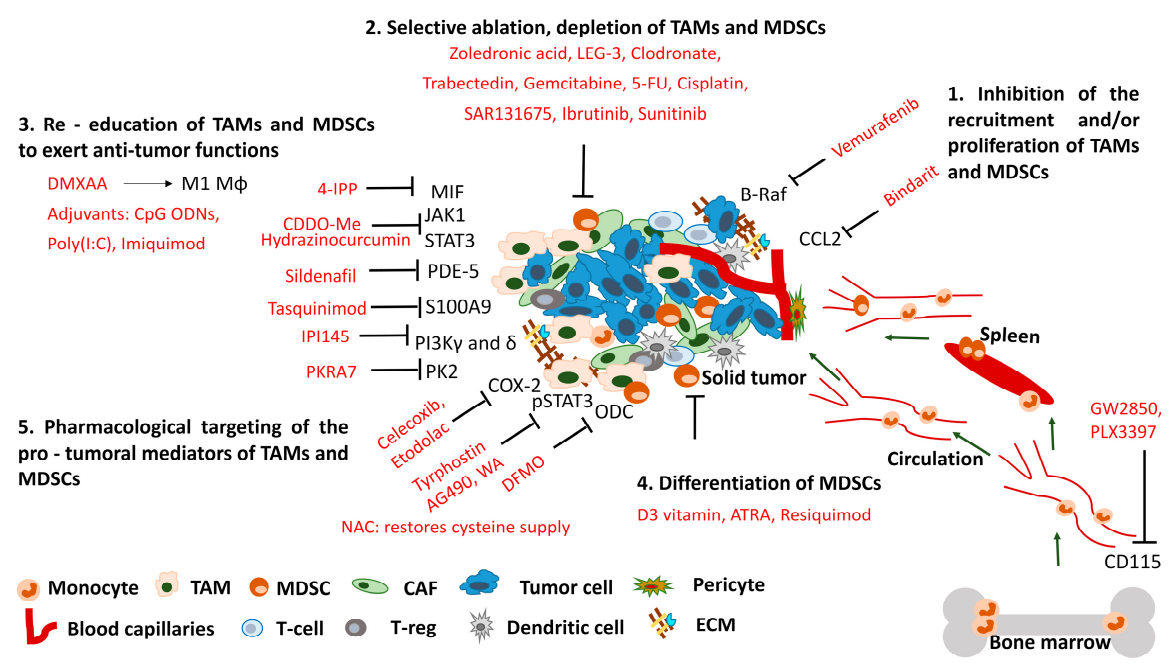

Figure 1. Small molecule-based therapeutic strategies to target TAMs and MDSCs in the tumor microenvironment. Solid tumor microenvironment constitutes a variety of cellular (MDSC, TAM, CAF, T-reg) and molecular stromal components (ECM) which hamper anti-tumor therapeutic response. We summarize current small molecule therapeutics (red) targeting TAMs and MDSCs. Possible therapeutic approaches include: (1) inhibition the recruitment and/or proliferation of monocytes/macrophages; (2) their selective ablation or (3) re-education to tumoricidal rather than tumor promoting; (4) differentiate immature myeloid cells or (5) pharmacologically inhibit their mediators responsible for pro-tumoral functions. Remarkably, modulation of MDSC and macrophage function is frequently an off-target effect of diverse drugs originally designed for other therapies. TAM: tumor-associated macrophage; MDSC: myeloid-derived suppressor cell; CAF: cancer-associated fibroblast; T-reg: regulatory T cell, ECM: extracellular matrix. Arrows refer to the direction of cell migration or stimulation; T-bar arrows refer to inhibition.

Since the authorization and introduction of new clinical applications of already approved drugs is much safer, shorter, cheaper and faster, it is advisable to screen for TAM and MDSC targeting compounds from the FDA approved drug library. Developing and adopting both in vitro and in vivo assays for high throughput screening campaigns to identify compounds, which (1) inhibit the recruitment or proliferation of TAMs and MDSCs; (2) deplete or (3) reprogram them by reverting their tumor promoting phenotype to anti-tumor effectors, and/or (4) differentiate immature myeloid cells; and finally (5) pharmacologically block their pro-tumoral mediators, are of high importance.

Several pathomechanisms such as immunosuppression, angiogenesis, metastases and altered metabolism link chronic inflammation and cancer progression to worsened patient condition. On the other hand, the anti-tumor effect of a diverse array of pharmacological interventions converges on inhibition or re-education of alternatively activated tumor infiltrating immune cells. Hereafter intensive research should be conducted to reveal in depth the molecular players of chronic inflammatory conditions involved in cancer development or in the establishment of tumor microenvironment in order to identify potential targets of anti-cancer therapeutic interventions.

Acknowledgments: The present work was partially supported by a grant (GINOP-2.3.2-15-2016-00001 for Csaba Vizler, Laszlo G. Puskas and Klara Kitajka) from the National Research, Development and Innovation Office (NKFI), Hungary.

Author Contributions: Gabor J. Szebeni, Csaba Vizler, Klara Kitajka and Laszlo G. Puskas wrote the paper; Lajos I. Nagy collected data.

Conflicts of Interest: The authors declare no conflict of interest. 


\section{References}

1. Balkwill, F.; Mantovani, A. Inflammation and cancer: Back to virchow? Lancet 2001, 357, 539-545. [CrossRef]

2. Mantovani, A.; Allavena, P.; Sica, A.; Balkwill, F. Cancer-related inflammation. Nature 2008, 454, 436-444. [CrossRef] [PubMed]

3. Hanahan, D.; Weinberg, R.A. The hallmarks of cancer. Cell 2000, 100, 57-70. [CrossRef]

4. Colotta, F.; Allavena, P.; Sica, A.; Garlanda, C.; Mantovani, A. Cancer-related inflammation, the seventh hallmark of cancer: Links to genetic instability. Carcinogenesis 2009, 30, 1073-1081. [CrossRef] [PubMed]

5. Hanahan, D.; Weinberg, R.A. Hallmarks of cancer: The next generation. Cell 2011, 144, 646-674. [CrossRef] [PubMed]

6. Porta, C.; Larghi, P.; Rimoldi, M.; Totaro, M.G.; Allavena, P.; Mantovani, A.; Sica, A. Cellular and molecular pathways linking inflammation and cancer. Immunobiology 2009, 214, 761-777. [CrossRef] [PubMed]

7. Polk, D.B.; Peek, R.M., Jr. Helicobacter pylori: Gastric cancer and beyond. Nat. Rev. Cancer 2010, 10, $403-414$. [CrossRef] [PubMed]

8. Goossens, N.; Hoshida, Y. Hepatitis C virus-induced hepatocellular carcinoma. Clin. Mol. Hepatol. 2015, 21, 105-114. [CrossRef] [PubMed]

9. Beaugerie, L.; Itzkowitz, S.H. Cancers complicating inflammatory bowel disease. N. Engl. J. Med. 2015, 372, 1441-1452. [PubMed]

10. Heinrich, E.L.; Walser, T.C.; Krysan, K.; Liclican, E.L.; Grant, J.L.; Rodriguez, N.L.; Dubinett, S.M. The inflammatory tumor microenvironment, epithelial mesenchymal transition and lung carcinogenesis. Cancer Microenviron. 2012, 5, 5-18. [CrossRef] [PubMed]

11. Yang, H.; Rivera, Z.; Jube, S.; Nasu, M.; Bertino, P.; Goparaju, C.; Franzoso, G.; Lotze, M.T.; Krausz, T.; Pass, H.I.; et al. Programmed necrosis induced by asbestos in human mesothelial cells causes high-mobility group box 1 protein release and resultant inflammation. Proc. Natl. Acad. Sci. USA 2010, 107, 12611-12616. [CrossRef] [PubMed]

12. Sfanos, K.S.; De Marzo, A.M. Prostate cancer and inflammation: The evidence. Histopathology 2012, 60, 199-215. [CrossRef] [PubMed]

13. Carmi, Y.; Dotan, S.; Rider, P.; Kaplanov, I.; White, M.R.; Baron, R.; Abutbul, S.; Huszar, M.; Dinarello, C.A.; Apte, R.N.; et al. The role of IL-1 $\beta$ in the early tumor cell-induced angiogenic response. J. Immunol. 2013, 190, 3500-3509. [CrossRef] [PubMed]

14. Tu, S.; Bhagat, G.; Cui, G.; Takaishi, S.; Kurt-Jones, E.A.; Rickman, B.; Betz, K.S.; Penz-Oesterreicher, M.; Bjorkdahl, O.; Fox, J.G.; et al. Overexpression of interleukin-1 $\beta$ induces gastric inflammation and cancer and mobilizes myeloid-derived suppressor cells in mice. Cancer Cell 2008, 14, 408-419. [CrossRef] [PubMed]

15. Katanov, C.; Lerrer, S.; Liubomirski, Y.; Leider-Trejo, L.; Meshel, T.; Bar, J.; Feniger-Barish, R.; Kamer, I.; Soria-Artzi, G.; Kahani, H.; et al. Regulation of the inflammatory profile of stromal cells in human breast cancer: Prominent roles for TNF-alpha and the NF-kB pathway. Stem Cell Res. Ther. 2015, 6, 87. [CrossRef] [PubMed]

16. Sethi, G.; Sung, B.; Aggarwal, B.B. TNF: A master switch for inflammation to cancer. Front. Biosci. 2008, 13, 5094-5107. [CrossRef] [PubMed]

17. Grivennikov, S.I.; Karin, M. Inflammatory cytokines in cancer: Tumour necrosis factor and interleukin 6 take the stage. Ann. Rheum. Dis. 2011, 70, i104-i108. [CrossRef] [PubMed]

18. Oft, M. IL-10: Master switch from tumor-promoting inflammation to antitumor immunity. Cancer Immunol. Res. 2014, 2, 194-199. [CrossRef] [PubMed]

19. Berg, D.J.; Davidson, N.; Kuhn, R.; Muller, W.; Menon, S.; Holland, G.; Thompson-Snipes, L.; Leach, M.W.; Rennick, D. Enterocolitis and colon cancer in interleukin-10-deficient mice are associated with aberrant cytokine production and CD4 ${ }^{+}$th1-like responses. J. Clin. Investig. 1996, 98, 1010-1020. [CrossRef] [PubMed]

20. Erdman, S.E.; Rao, V.P.; Poutahidis, T.; Ihrig, M.M.; Ge, Z.; Feng, Y.; Tomczak, M.; Rogers, A.B.; Horwitz, B.H.; Fox, J.G. CD4 ${ }^{+} \mathrm{CD} 25^{+}$regulatory lymphocytes require interleukin 10 to interrupt colon carcinogenesis in mice. Cancer Res. 2003, 63, 6042-6050. [PubMed]

21. Tili, E.; Croce, C.M.; Michaille, J.J. miR-155: On the crosstalk between inflammation and cancer. Int. Rev. Immunol. 2009, 28, 264-284. [CrossRef] [PubMed] 
22. Tili, E.; Michaille, J.J.; Wernicke, D.; Alder, H.; Costinean, S.; Volinia, S.; Croce, C.M. Mutator activity induced by microRNA-155 (miR-155) links inflammation and cancer. Proc. Natl. Acad. Sci. USA 2011, 108, 4908-4913. [CrossRef] [PubMed]

23. Valeri, N.; Gasparini, P.; Fabbri, M.; Braconi, C.; Veronese, A.; Lovat, F.; Adair, B.; Vannini, I.; Fanini, F.; Bottoni, A.; et al. Modulation of mismatch repair and genomic stability by miR-155. Proc. Natl. Acad. Sci. USA 2010, 107, 6982-6987. [CrossRef] [PubMed]

24. Kamp, D.W.; Shacter, E.; Weitzman, S.A. Chronic inflammation and cancer: The role of the mitochondria. Oncology 2011, 25, 400-410, 413. [PubMed]

25. Hiraku, Y. Formation of 8-nitroguanine, a nitrative DNA lesion, in inflammation-related carcinogenesis and its significance. Environ. Health Prev. Med. 2010, 15, 63-72. [CrossRef] [PubMed]

26. Gungor, N.; Knaapen, A.M.; Munnia, A.; Peluso, M.; Haenen, G.R.; Chiu, R.K.; Godschalk, R.W.; van Schooten, F.J. Genotoxic effects of neutrophils and hypochlorous acid. Mutagenesis 2010, 25, 149-154. [CrossRef] [PubMed]

27. Marengo, B.; Nitti, M.; Furfaro, A.L.; Colla, R.; Ciucis, C.D.; Marinari, U.M.; Pronzato, M.A.; Traverso, N.; Domenicotti, C. Redox homeostasis and cellular antioxidant systems: Crucial players in cancer growth and therapy. Oxid. Med. Cell. Longev. 2016, 2016, 6235641. [CrossRef] [PubMed]

28. Chen, X.; Song, M.; Zhang, B.; Zhang, Y. Reactive oxygen species regulate T cell immune response in the tumor microenvironment. Oxid. Med. Cell. Longev. 2016, 2016, 1580967. [CrossRef] [PubMed]

29. Deng, T.; Lyon, C.J.; Bergin, S.; Caligiuri, M.A.; Hsueh, W.A. Obesity, inflammation, and cancer. Annu. Rev. Pathol. 2016, 11, 421-449. [CrossRef] [PubMed]

30. Umar, A.; Steele, V.E.; Menter, D.G.; Hawk, E.T. Mechanisms of nonsteroidal anti-inflammatory drugs in cancer prevention. Semin. Oncol. 2016, 43, 65-77. [CrossRef] [PubMed]

31. Allaj, V.; Guo, C.; Nie, D. Non-steroid anti-inflammatory drugs, prostaglandins, and cancer. Cell Biosci. 2013, 3, 8. [CrossRef] [PubMed]

32. Sica, A.; Erreni, M.; Allavena, P.; Porta, C. Macrophage polarization in pathology. Cell. Mol. Life Sci. 2015, 72, 4111-4126. [CrossRef] [PubMed]

33. Porta, C.; Riboldi, E.; Ippolito, A.; Sica, A. Molecular and epigenetic basis of macrophage polarized activation. Semin. Immunol. 2015, 27, 237-248. [CrossRef] [PubMed]

34. Kumar, V.; Patel, S.; Tcyganov, E.; Gabrilovich, D.I. The nature of myeloid-derived suppressor cells in the tumor microenvironment. Trends Immunol. 2016, 37, 208-220. [CrossRef] [PubMed]

35. Gabrilovich, D.I.; Ostrand-Rosenberg, S.; Bronte, V. Coordinated regulation of myeloid cells by tumours. Nat. Rev. Immunol. 2012, 12, 253-268. [CrossRef] [PubMed]

36. Katoh, H.; Watanabe, M. Myeloid-derived suppressor cells and therapeutic strategies in cancer. Mediat. Inflamm. 2015, 2015, 159269. [CrossRef] [PubMed]

37. Shipp, C.; Speigl, L.; Janssen, N.; Martens, A.; Pawelec, G. A clinical and biological perspective of human myeloid-derived suppressor cells in cancer. Cell. Mol. Life Sci. 2016, 73, 4043-4061. [CrossRef] [PubMed]

38. Turley, S.J.; Cremasco, V.; Astarita, J.L. Immunological hallmarks of stromal cells in the tumour microenvironment. Nat. Rev. Immunol. 2015, 15, 669-682. [CrossRef] [PubMed]

39. Kim, J.; Bae, J.S. Tumor-associated macrophages and neutrophils in tumor microenvironment. Mediat. Inflamm. 2016, 2016, 6058147. [CrossRef] [PubMed]

40. Franklin, R.A.; Li, M.O. Ontogeny of tumor-associated macrophages and its implication in cancer regulation. Trends Cancer 2016, 2, 20-34. [CrossRef] [PubMed]

41. Caronni, N.; Savino, B.; Bonecchi, R. Myeloid cells in cancer-related inflammation. Immunobiology 2015, 220, 249-253. [CrossRef] [PubMed]

42. Zhao, Y.; Wu, T.; Shao, S.; Shi, B.; Zhao, Y. Phenotype, development, and biological function of myeloid-derived suppressor cells. Oncoimmunology 2016, 5, e1004983. [CrossRef] [PubMed]

43. Schmid, M.C.; Varner, J.A. Myeloid cells in tumor inflammation. Vasc. Cell 2012, 4, 14. [CrossRef] [PubMed]

44. Jackaman, C.; Nelson, D.J. Are macrophages, myeloid derived suppressor cells and neutrophils mediators of local suppression in healthy and cancerous tissues in aging hosts? Exp. Gerontol. 2014, 54, 53-57. [CrossRef] [PubMed]

45. Youn, J.I.; Nagaraj, S.; Collazo, M.; Gabrilovich, D.I. Subsets of myeloid-derived suppressor cells in tumor-bearing mice. J. Immunol. 2008, 181, 5791-5802. [CrossRef] [PubMed] 
46. Gabrilovich, D.I.; Nagaraj, S. Myeloid-derived suppressor cells as regulators of the immune system. Nat. Rev. Immunol. 2009, 9, 162-174. [CrossRef] [PubMed]

47. Nagaraj, S.; Gupta, K.; Pisarev, V.; Kinarsky, L.; Sherman, S.; Kang, L.; Herber, D.L.; Schneck, J.; Gabrilovich, D.I. Altered recognition of antigen is a mechanism of CD8 ${ }^{+} \mathrm{T}$ cell tolerance in cancer. Nat. Med. 2007, 13, 828-835. [CrossRef] [PubMed]

48. Ostrand-Rosenberg, S.; Sinha, P.; Beury, D.W.; Clements, V.K. Cross-talk between myeloid-derived suppressor cells (MDSC), macrophages, and dendritic cells enhances tumor-induced immune suppression. Semin. Cancer Biol. 2012, 22, 275-281. [CrossRef] [PubMed]

49. Sica, A.; Porta, C.; Morlacchi, S.; Banfi, S.; Strauss, L.; Rimoldi, M.; Totaro, M.G.; Riboldi, E. Origin and functions of tumor-associated myeloid cells (TAMCS). Cancer Microenviron. 2012, 5, 133-149. [CrossRef] [PubMed]

50. Mao, Y.; Poschke, I.; Wennerberg, E.; Pico de Coana, Y.; Egyhazi Brage, S.; Schultz, I.; Hansson, J.; Masucci, G.; Lundqvist, A.; Kiessling, R. Melanoma-educated $\mathrm{CD} 14^{+}$cells acquire a myeloid-derived suppressor cell phenotype through COX-2-dependent mechanisms. Cancer Res. 2013, 73, 3877-3887. [CrossRef] [PubMed]

51. Sinha, P.; Clements, V.K.; Bunt, S.K.; Albelda, S.M.; Ostrand-Rosenberg, S. Cross-talk between myeloid-derived suppressor cells and macrophages subverts tumor immunity toward a type 2 response. J. Immunol. 2007, 179, 977-983. [CrossRef] [PubMed]

52. Kumar, V.; Gabrilovich, D.I. Hypoxia-inducible factors in regulation of immune responses in tumour microenvironment. Immunology 2014, 143, 512-519. [CrossRef] [PubMed]

53. Bloch, O.; Crane, C.A.; Kaur, R.; Safaee, M.; Rutkowski, M.J.; Parsa, A.T. Gliomas promote immunosuppression through induction of B7-H1 expression in tumor-associated macrophages. Clin. Cancer Res. 2013, 19, 3165-3175. [CrossRef] [PubMed]

54. Kryczek, I.; Zou, L.; Rodriguez, P.; Zhu, G.; Wei, S.; Mottram, P.; Brumlik, M.; Cheng, P.; Curiel, T.; Myers, L.; et al. B7-H4 expression identifies a novel suppressive macrophage population in human ovarian carcinoma. J. Exp. Med. 2006, 203, 871-881. [CrossRef] [PubMed]

55. Daurkin, I.; Eruslanov, E.; Stoffs, T.; Perrin, G.Q.; Algood, C.; Gilbert, S.M.; Rosser, C.J.; Su, L.M.; Vieweg, J.; Kusmartsev, S. Tumor-associated macrophages mediate immunosuppression in the renal cancer microenvironment by activating the 15-lipoxygenase-2 pathway. Cancer Res. 2011, 71, 6400-6409. [CrossRef] [PubMed]

56. Galdiero, M.R.; Garlanda, C.; Jaillon, S.; Marone, G.; Mantovani, A. Tumor associated macrophages and neutrophils in tumor progression. J. Cell. Physiol. 2013, 228, 1404-1412. [CrossRef] [PubMed]

57. Wang, B.; Li, Q.; Qin, L.; Zhao, S.; Wang, J.; Chen, X. Transition of tumor-associated macrophages from MHC class II(hi) to MHC class II(low) mediates tumor progression in mice. BMC Immunol. 2011, 12, 43. [CrossRef] [PubMed]

58. Cekic, C.; Day, Y.J.; Sag, D.; Linden, J. Myeloid expression of adenosine A2A receptor suppresses T and NK cell responses in the solid tumor microenvironment. Cancer Res. 2014, 74, 7250-7259. [CrossRef] [PubMed]

59. Sharma, S.K.; Chintala, N.K.; Vadrevu, S.K.; Patel, J.; Karbowniczek, M.; Markiewski, M.M. Pulmonary alveolar macrophages contribute to the premetastatic niche by suppressing antitumor $\mathrm{T}$ cell responses in the lungs. J. Immunol. 2015, 194, 5529-5538. [CrossRef] [PubMed]

60. Ugel, S.; Peranzoni, E.; Desantis, G.; Chioda, M.; Walter, S.; Weinschenk, T.; Ochando, J.C.; Cabrelle, A.; Mandruzzato, S.; Bronte, V. Immune tolerance to tumor antigens occurs in a specialized environment of the spleen. Cell. Rep. 2012, 2, 628-639. [CrossRef] [PubMed]

61. Song, J.; Lee, J.; Kim, J.; Jo, S.; Kim, Y.J.; Baek, J.E.; Kwon, E.S.; Lee, K.P.; Yang, S.; Kwon, K.S.; et al. Pancreatic adenocarcinoma up-regulated factor (PAUF) enhances the accumulation and functional activity of myeloid-derived suppressor cells (MDSCs) in pancreatic cancer. Oncotarget 2016. [CrossRef] [PubMed]

62. Pucci, F.; Pittet, M.J. Molecular pathways: Tumor-derived microvesicles and their interactions with immune cells in vivo. Clin. Cancer Res. 2013, 19, 2598-2604. [CrossRef] [PubMed]

63. Mao, Y.; Poschke, I.; Kiessling, R. Tumour-induced immune suppression: Role of inflammatory mediators released by myelomonocytic cells. J. Intern. Med. 2014, 276, 154-170. [CrossRef] [PubMed]

64. Naumov, G.N.; Bender, E.; Zurakowski, D.; Kang, S.Y.; Sampson, D.; Flynn, E.; Watnick, R.S.; Straume, O.; Akslen, L.A.; Folkman, J.; et al. A model of human tumor dormancy: An angiogenic switch from the nonangiogenic phenotype. J. Natl. Cancer Inst. 2006, 98, 316-325. [CrossRef] [PubMed] 
65. Lin, E.Y.; Li, J.F.; Gnatovskiy, L.; Deng, Y.; Zhu, L.; Grzesik, D.A.; Qian, H.; Xue, X.N.; Pollard, J.W. Macrophages regulate the angiogenic switch in a mouse model of breast cancer. Cancer Res. 2006, 66, 11238-11246. [CrossRef] [PubMed]

66. Espinosa, I.; Jose Carnicer, M.; Catasus, L.; Canet, B.; D’Angelo, E.; Zannoni, G.F.; Prat, J. Myometrial invasion and lymph node metastasis in endometrioid carcinomas: Tumor-associated macrophages, microvessel density, and HIF1A have a crucial role. Am. J. Surg. Pathol. 2010, 34, 1708-1714. [CrossRef] [PubMed]

67. Shojaei, F.; Wu, X.; Zhong, C.; Yu, L.; Liang, X.H.; Yao, J.; Blanchard, D.; Bais, C.; Peale, F.V.; van Bruggen, N.; et al. Bv8 regulates myeloid-cell-dependent tumour angiogenesis. Nature 2007, 450, 825-831. [CrossRef] [PubMed]

68. Varney, M.L.; Olsen, K.J.; Mosley, R.L.; Singh, R.K. Paracrine regulation of vascular endothelial growth factor-A expression during macrophage-melanoma cell interaction: Role of monocyte chemotactic protein-1 and macrophage colony-stimulating factor. J. Interferon Cytokine Res. 2005, 25, 674-683. [CrossRef] [PubMed]

69. Toge, H.; Inagaki, T.; Kojimoto, Y.; Shinka, T.; Hara, I. Angiogenesis in renal cell carcinoma: The role of tumor-associated macrophages. Int. J. Urol. 2009, 16, 801-807. [CrossRef] [PubMed]

70. Staudt, N.D.; Jo, M.; Hu, J.; Bristow, J.M.; Pizzo, D.P.; Gaultier, A.; VandenBerg, S.R.; Gonias, S.L. Myeloid cell receptor LRP1/CD91 regulates monocyte recruitment and angiogenesis in tumors. Cancer Res. 2013, 73, 3902-3912. [CrossRef] [PubMed]

71. Chen, P.; Huang, Y.; Bong, R.; Ding, Y.; Song, N.; Wang, X.; Song, X.; Luo, Y. Tumor-associated macrophages promote angiogenesis and melanoma growth via adrenomedullin in a paracrine and autocrine manner. Clin. Cancer Res. 2011, 17, 7230-7239. [CrossRef] [PubMed]

72. Sierra, J.R.; Corso, S.; Caione, L.; Cepero, V.; Conrotto, P.; Cignetti, A.; Piacibello, W.; Kumanogoh, A.; Kikutani, H.; Comoglio, P.M.; et al. Tumor angiogenesis and progression are enhanced by SEMA4D produced by tumor-associated macrophages. J. Exp. Med. 2008, 205, 1673-1685. [CrossRef] [PubMed]

73. Kale, S.; Raja, R.; Thorat, D.; Soundararajan, G.; Patil, T.V.; Kundu, G.C. Osteopontin signaling upregulates cyclooxygenase-2 expression in tumor-associated macrophages leading to enhanced angiogenesis and melanoma growth via $\alpha 9 \beta 1$ integrin. Oncogene 2014, 33, 2295-2306. [CrossRef] [PubMed]

74. Ojalvo, L.S.; Whittaker, C.A.; Condeelis, J.S.; Pollard, J.W. Gene expression analysis of macrophages that facilitate tumor invasion supports a role for Wnt-signaling in mediating their activity in primary mammary tumors. J. Immunol. 2010, 184, 702-712. [CrossRef] [PubMed]

75. Binsfeld, M.; Muller, J.; Lamour, V.; de Veirman, K.; de Raeve, H.; Bellahcene, A.; van Valckenborgh, E.; Baron, F.; Beguin, Y.; Caers, J.; et al. Granulocytic myeloid-derived suppressor cells promote angiogenesis in the context of multiple myeloma. Oncotarget 2016, 7, 37931-37943. [CrossRef] [PubMed]

76. Venneri, M.A.; de Palma, M.; Ponzoni, M.; Pucci, F.; Scielzo, C.; Zonari, E.; Mazzieri, R.; Doglioni, C.; Naldini, L. Identification of proangiogenic TIE2-expressing monocytes (TEMs) in human peripheral blood and cancer. Blood 2007, 109, 5276-5285. [CrossRef] [PubMed]

77. Lewis, C.E.; de Palma, M.; Naldini, L. TIE2-expressing monocytes and tumor angiogenesis: Regulation by hypoxia and angiopoietin-2. Cancer Res. 2007, 67, 8429-8432. [CrossRef] [PubMed]

78. Nieto, M.A.; Huang, R.Y.; Jackson, R.A.; Thiery, J.P. EMT: 2016. Cell 2016, 166, 21-45. [CrossRef] [PubMed]

79. Toh, B.; Wang, X.; Keeble, J.; Sim, W.J.; Khoo, K.; Wong, W.C.; Kato, M.; Prevost-Blondel, A.; Thiery, J.P.; Abastado, J.P. Mesenchymal transition and dissemination of cancer cells is driven by myeloid-derived suppressor cells infiltrating the primary tumor. PLoS Biol. 2011, 9, e1001162. [CrossRef] [PubMed]

80. Liu, C.Y.; Xu, J.Y.; Shi, X.Y.; Huang, W.; Ruan, T.Y.; Xie, P.; Ding, J.L. M2-polarized tumor-associated macrophages promoted epithelial-mesenchymal transition in pancreatic cancer cells, partially through TLR4/IL-10 signaling pathway. Lab. Investig. 2013, 93, 844-854. [CrossRef] [PubMed]

81. Li, Z.L.; Ye, S.B.; OuYang, L.Y.; Zhang, H.; Chen, Y.S.; He, J.; Chen, Q.Y.; Qian, C.N.; Zhang, X.S.; Cui, J.; et al. Cox-2 promotes metastasis in nasopharyngeal carcinoma by mediating interactions between cancer cells and myeloid-derived suppressor cells. Oncoimmunology 2015, 4, e1044712. [CrossRef] [PubMed]

82. Suarez-Carmona, M.; Bourcy, M.; Lesage, J.; Leroi, N.; Syne, L.; Blacher, S.; Hubert, P.; Erpicum, C.; Foidart, J.M.; Delvenne, P.; et al. Soluble factors regulated by epithelial-mesenchymal transition mediate tumour angiogenesis and myeloid cell recruitment. J. Pathol. 2015, 236, 491-504. [CrossRef] [PubMed]

83. Fischer, K.R.; Durrans, A.; Lee, S.; Sheng, J.; Li, F.; Wong, S.T.; Choi, H.; El Rayes, T.; Ryu, S.; Troeger, J.; et al. Epithelial-to-mesenchymal transition is not required for lung metastasis but contributes to chemoresistance. Nature 2015, 527, 472-476. [CrossRef] [PubMed] 
84. Zheng, X.; Carstens, J.L.; Kim, J.; Scheible, M.; Kaye, J.; Sugimoto, H.; Wu, C.C.; LeBleu, V.S.; Kalluri, R. Epithelial-to-mesenchymal transition is dispensable for metastasis but induces chemoresistance in pancreatic cancer. Nature 2015, 527, 525-530. [CrossRef] [PubMed]

85. Nassar, D.; Blanpain, C. Cancer stem cells: Basic concepts and therapeutic implications. Annu. Rev. Pathol. 2016, 11, 47-76. [CrossRef] [PubMed]

86. Cui, T.X.; Kryczek, I.; Zhao, L.; Zhao, E.; Kuick, R.; Roh, M.H.; Vatan, L.; Szeliga, W.; Mao, Y.; Thomas, D.G.; et al. Myeloid-derived suppressor cells enhance stemness of cancer cells by inducing microRNA101 and suppressing the corepressor CtBP2. Immunity 2013, 39, 611-621. [CrossRef] [PubMed]

87. Deng, Z.; Rong, Y.; Teng, Y.; Zhuang, X.; Samykutty, A.; Mu, J.; Zhang, L.; Cao, P.; Yan, J.; Miller, D.; et al. Exosomes miR-126a released from MDSC induced by DOX treatment promotes lung metastasis. Oncogene 2016. [CrossRef] [PubMed]

88. Hagemann, T.; Wilson, J.; Kulbe, H.; Li, N.F.; Leinster, D.A.; Charles, K.; Klemm, F.; Pukrop, T.; Binder, C.; Balkwill, F.R. Macrophages induce invasiveness of epithelial cancer cells via NF-kB and JNK. J. Immunol. 2005, 175, 1197-1205. [CrossRef] [PubMed]

89. Pukrop, T.; Klemm, F.; Hagemann, T.; Gradl, D.; Schulz, M.; Siemes, S.; Trumper, L.; Binder, C. Wnt 5a signaling is critical for macrophage-induced invasion of breast cancer cell lines. Proc. Natl. Acad. Sci. USA 2006, 103, 5454-5459. [CrossRef] [PubMed]

90. Lin, C.Y.; Lin, C.J.; Chen, K.H.; Wu, J.C.; Huang, S.H.; Wang, S.M. Macrophage activation increases the invasive properties of hepatoma cells by destabilization of the adherens junction. FEBS Lett. 2006, 580, 3042-3050. [CrossRef] [PubMed]

91. Tjiu, J.W.; Chen, J.S.; Shun, C.T.; Lin, S.J.; Liao, Y.H.; Chu, C.Y.; Tsai, T.F.; Chiu, H.C.; Dai, Y.S.; Inoue, H.; et al. Tumor-associated macrophage-induced invasion and angiogenesis of human basal cell carcinoma cells by cyclooxygenase-2 induction. J. Investig. Dermatol. 2009, 129, 1016-1025. [CrossRef] [PubMed]

92. Wen, S.W.; Ager, E.I.; Christophi, C. Bimodal role of Kupffer cells during colorectal cancer liver metastasis. Cancer Biol. Ther. 2013, 14, 606-613. [CrossRef] [PubMed]

93. Kitamura, T.; Qian, B.Z.; Pollard, J.W. Immune cell promotion of metastasis. Nat. Rev. Immunol. 2015, 15, 73-86. [CrossRef] [PubMed]

94. Smith, H.A.; Kang, Y. The metastasis-promoting roles of tumor-associated immune cells. J. Mol. Med. 2013, 91, 411-429. [CrossRef] [PubMed]

95. Riboldi, E.; Porta, C.; Morlacchi, S.; Viola, A.; Mantovani, A.; Sica, A. Hypoxia-mediated regulation of macrophage functions in pathophysiology. Int. Immunol. 2013, 25, 67-75. [CrossRef] [PubMed]

96. Odegaard, J.I.; Chawla, A. Alternative macrophage activation and metabolism. Annu. Rev. Pathol. 2011, 6, 275-297. [CrossRef] [PubMed]

97. O'Neill, L.A.; Hardie, D.G. Metabolism of inflammation limited by AMPK and pseudo-starvation. Nature 2013, 493, 346-355. [CrossRef] [PubMed]

98. Liu, T.F.; Yoza, B.K.; El Gazzar, M.; Vachharajani, V.T.; McCall, C.E. NAD ${ }^{+}$-dependent SIRT1 deacetylase participates in epigenetic reprogramming during endotoxin tolerance. J. Biol. Chem. 2011, 286, 9856-9864. [CrossRef] [PubMed]

99. Hossain, F.; Al-Khami, A.A.; Wyczechowska, D.; Hernandez, C.; Zheng, L.; Reiss, K.; Valle, L.D.; Trillo-Tinoco, J.; Maj, T.; Zou, W.; et al. Inhibition of fatty acid oxidation modulates immunosuppressive functions of myeloid-derived suppressor cells and enhances cancer therapies. Cancer Immunol. Res. 2015, 3, 1236-1247. [CrossRef] [PubMed]

100. Husain, Z.; Huang, Y.; Seth, P.; Sukhatme, V.P. Tumor-derived lactate modifies antitumor immune response: Effect on myeloid-derived suppressor cells and NK cells. J. Immunol. 2013, 191, 1486-1495. [CrossRef] [PubMed]

101. Devi, K.P.; Rajavel, T.; Russo, G.L.; Daglia, M.; Nabavi, S.F.; Nabavi, S.M. Molecular targets of omega-3 fatty acids for cancer therapy. Anticancer Agents Med. Chem. 2015, 15, 888-895. [CrossRef] [PubMed]

102. Azrad, M.; Turgeon, C.; Demark-Wahnefried, W. Current evidence linking polyunsaturated fatty acids with cancer risk and progression. Front. Oncol. 2013, 3, 224. [CrossRef] [PubMed]

103. Antal, O.; Peter, M.; Hackler, L., Jr.; Man, I.; Szebeni, G.; Ayaydin, F.; Hideghety, K.; Vigh, L.; Kitajka, K.; Balogh, G.; et al. Lipidomic analysis reveals a radiosensitizing role of $\gamma$-linolenic acid in glioma cells. Biochim. Biophys. Acta 2015, 1851, 1271-1282. [CrossRef] [PubMed] 
104. Yan, D.; Yang, Q.; Shi, M.; Zhong, L.; Wu, C.; Meng, T.; Yin, H.; Zhou, J. Polyunsaturated fatty acids promote the expansion of myeloid-derived suppressor cells by activating the JAK/STAT3 pathway. Eur. J. Immunol. 2013, 43, 2943-2955. [CrossRef] [PubMed]

105. Komohara, Y.; Niino, D.; Saito, Y.; Ohnishi, K.; Horlad, H.; Ohshima, K.; Takeya, M. Clinical significance of $\mathrm{CD}_{163}{ }^{+}$tumor-associated macrophages in patients with adult T-cell leukemia/lymphoma. Cancer Sci. 2013, 104, 945-951. [CrossRef] [PubMed]

106. Cairo, G.; Recalcati, S.; Mantovani, A.; Locati, M. Iron trafficking and metabolism in macrophages: Contribution to the polarized phenotype. Trends Immunol. 2011, 32, 241-247. [CrossRef] [PubMed]

107. Biswas, S.K.; Mantovani, A. Orchestration of metabolism by macrophages. Cell Metab. 2012, 15, $432-437$. [CrossRef] [PubMed]

108. OuYang, L.Y.; Wu, X.J.; Ye, S.B.; Zhang, R.X.; Li, Z.L.; Liao, W.; Pan, Z.Z.; Zheng, L.M.; Zhang, X.S.; Wang, Z.; et al. Tumor-induced myeloid-derived suppressor cells promote tumor progression through oxidative metabolism in human colorectal cancer. J. Transl. Med. 2015, 13, 47. [CrossRef] [PubMed]

109. Biswas, S.K. Metabolic reprogramming of immune cells in cancer progression. Immunity 2015, 43, 435-449. [CrossRef] [PubMed]

110. Ryder, M.; Ghossein, R.A.; Ricarte-Filho, J.C.; Knauf, J.A.; Fagin, J.A. Increased density of tumor-associated macrophages is associated with decreased survival in advanced thyroid cancer. Endocr. Relat. Cancer 2008, 15, 1069-1074. [CrossRef] [PubMed]

111. Steidl, C.; Lee, T.; Shah, S.P.; Farinha, P.; Han, G.; Nayar, T.; Delaney, A.; Jones, S.J.; Iqbal, J.; Weisenburger, D.D.; et al. Tumor-associated macrophages and survival in classic Hodgkin's lymphoma. N. Engl. J. Med. 2010, 362, 875-885. [CrossRef] [PubMed]

112. Fujiwara, T.; Fukushi, J.; Yamamoto, S.; Matsumoto, Y.; Setsu, N.; Oda, Y.; Yamada, H.; Okada, S.; Watari, K.; Ono, M.; et al. Macrophage infiltration predicts a poor prognosis for human ewing sarcoma. Am. J. Pathol. 2011, 179, 1157-1170. [CrossRef] [PubMed]

113. Zhang, B.; Yao, G.; Zhang, Y.; Gao, J.; Yang, B.; Rao, Z. M2-polarized tumor-associated macrophages are associated with poor prognoses resulting from accelerated lymphangiogenesis in lung adenocarcinoma. Clinics 2011, 66, 1879-1886. [CrossRef] [PubMed]

114. Cai, Q.C.; Liao, H.; Lin, S.X.; Xia, Y.; Wang, X.X.; Gao, Y.; Lin, Z.X.; Lu, J.B.; Huang, H.Q. High expression of tumor-infiltrating macrophages correlates with poor prognosis in patients with diffuse large B-cell lymphoma. Med. Oncol. 2012, 29, 2317-2322. [CrossRef] [PubMed]

115. Zhang, Q.W.; Liu, L.; Gong, C.Y.; Shi, H.S.; Zeng, Y.H.; Wang, X.Z.; Zhao, Y.W.; Wei, Y.Q. Prognostic significance of tumor-associated macrophages in solid tumor: A meta-analysis of the literature. PLoS ONE 2012, 7, e50946. [CrossRef] [PubMed]

116. Ong, S.M.; Tan, Y.C.; Beretta, O.; Jiang, D.; Yeap, W.H.; Tai, J.J.; Wong, W.C.; Yang, H.; Schwarz, H.; Lim, K.H.; et al. Macrophages in human colorectal cancer are pro-inflammatory and prime T cells towards an anti-tumour type-1 inflammatory response. Eur. J. Immunol. 2012, 42, 89-100. [CrossRef] [PubMed]

117. Gulubova, M.; Manolova, I.; Ananiev, J. The density of macrophages in colorectal cancer is inversely correlated to TGF-beta1 expression and patients' survival. Virchows Arch. 2012, 461, S178.

118. Kang, J.C.; Chen, J.S.; Lee, C.H.; Chang, J.J.; Shieh, Y.S. Intratumoral macrophage counts correlate with tumor progression in colorectal cancer. J. Surg. Oncol. 2010, 102, 242-248. [CrossRef] [PubMed]

119. Gabitass, R.F.; Annels, N.E.; Stocken, D.D.; Pandha, H.A.; Middleton, G.W. Elevated myeloid-derived suppressor cells in pancreatic, esophageal and gastric cancer are an independent prognostic factor and are associated with significant elevation of the Th2 cytokine interleukin-13. Cancer Immunol. Immunother. 2011, 60, 1419-1430. [CrossRef] [PubMed]

120. Weide, B.; Martens, A.; Zelba, H.; Stutz, C.; Derhovanessian, E.; di Giacomo, A.M.; Maio, M.; Sucker, A.; Schilling, B.; Schadendorf, D.; et al. Myeloid-derived suppressor cells predict survival of patients with advanced melanoma: Comparison with regulatory T cells and NY-ESO-1- or melan-A-specific T cells. Clin. Cancer Res. 2014, 20, 1601-1609. [CrossRef] [PubMed]

121. Gazzaniga, S.; Bravo, A.I.; Guglielmotti, A.; van Rooijen, N.; Maschi, F.; Vecchi, A.; Mantovani, A.; Mordoh, J.; Wainstok, R. Targeting tumor-associated macrophages and inhibition of MCP-1 reduce angiogenesis and tumor growth in a human melanoma xenograft. J. Investig. Dermatol. 2007, 127, 2031-2041. [CrossRef] [PubMed] 
122. Zollo, M.; di Dato, V.; Spano, D.; de Martino, D.; Liguori, L.; Marino, N.; Vastolo, V.; Navas, L.; Garrone, B.; Mangano, G.; et al. Targeting monocyte chemotactic protein-1 synthesis with bindarit induces tumor regression in prostate and breast cancer animal models. Clin. Exp. Metastasis 2012, 29, 585-601. [CrossRef] [PubMed]

123. Fridlender, Z.G.; Kapoor, V.; Buchlis, G.; Cheng, G.; Sun, J.; Wang, L.C.; Singhal, S.; Snyder, L.A.; Albelda, S.M. Monocyte chemoattractant protein-1 blockade inhibits lung cancer tumor growth by altering macrophage phenotype and activating CD8 ${ }^{+}$cells. Am. J. Respir. Cell Mol. Biol. 2011, 44, 230-237. [CrossRef] [PubMed]

124. Xu, J.; Escamilla, J.; Mok, S.; David, J.; Priceman, S.; West, B.; Bollag, G.; McBride, W.; Wu, L. CSF1R signaling blockade stanches tumor-infiltrating myeloid cells and improves the efficacy of radiotherapy in prostate cancer. Cancer Res. 2013, 73, 2782-2794. [CrossRef] [PubMed]

125. Ryder, M.; Gild, M.; Hohl, T.M.; Pamer, E.; Knauf, J.; Ghossein, R.; Joyce, J.A.; Fagin, J.A. Genetic and pharmacological targeting of CSF-1/CSF-1R inhibits tumor-associated macrophages and impairs BRAF-induced thyroid cancer progression. PLOS ONE 2013, 8, e54302. [CrossRef] [PubMed]

126. Zhu, Y.; Knolhoff, B.L.; Meyer, M.A.; Nywening, T.M.; West, B.L.; Luo, J.; Wang-Gillam, A.; Goedegebuure, S.P.; Linehan, D.C.; DeNardo, D.G. CSF1/CSF1R blockade reprograms tumor-infiltrating macrophages and improves response to T-cell checkpoint immunotherapy in pancreatic cancer models. Cancer Res. 2014, 74, 5057-5069. [CrossRef] [PubMed]

127. Strauss, L.; Sangaletti, S.; Consonni, F.M.; Szebeni, G.; Morlacchi, S.; Totaro, M.G.; Porta, C.; Anselmo, A.; Tartari, S.; Doni, A.; et al. RORC1 regulates tumor-promoting "emergency" granulo-monocytopoiesis. Cancer Cell 2015, 28, 253-269. [CrossRef] [PubMed]

128. Schilling, B.; Sucker, A.; Griewank, K.; Zhao, F.; Weide, B.; Gorgens, A.; Giebel, B.; Schadendorf, D.; Paschen, A. Vemurafenib reverses immunosuppression by myeloid derived suppressor cells. Int. J. Cancer 2013, 133, 1653-1663. [CrossRef] [PubMed]

129. Fend, L.; Accart, N.; Kintz, J.; Cochin, S.; Reymann, C.; Le Pogam, F.; Marchand, J.B.; Menguy, T.; Slos, P.; Rooke, R.; et al. Therapeutic effects of anti-CD115 monoclonal antibody in mouse cancer models through dual inhibition of tumor-associated macrophages and osteoclasts. PLoS ONE 2013, 8, e73310. [CrossRef] [PubMed]

130. Lohela, M.; Casbon, A.J.; Olow, A.; Bonham, L.; Branstetter, D.; Weng, N.; Smith, J.; Werb, Z. Intravital imaging reveals distinct responses of depleting dynamic tumor-associated macrophage and dendritic cell subpopulations. Proc. Natl. Acad. Sci. USA 2014, 111, E5086-E5095. [CrossRef] [PubMed]

131. Rietkotter, E.; Menck, K.; Bleckmann, A.; Farhat, K.; Schaffrinski, M.; Schulz, M.; Hanisch, U.K.; Binder, C.; Pukrop, T. Zoledronic acid inhibits macrophage/microglia-assisted breast cancer cell invasion. Oncotarget 2013, 4, 1449-1460. [CrossRef] [PubMed]

132. Coscia, M.; Quaglino, E.; Iezzi, M.; Curcio, C.; Pantaleoni, F.; Riganti, C.; Holen, I.; Monkkonen, H.; Boccadoro, M.; Forni, G.; et al. Zoledronic acid repolarizes tumour-associated macrophages and inhibits mammary carcinogenesis by targeting the mevalonate pathway. J. Cell. Mol. Med. 2010, 14, 2803-2815. [CrossRef] [PubMed]

133. Lin, Y.; Wei, C.; Liu, Y.; Qiu, Y.; Liu, C.; Guo, F. Selective ablation of tumor-associated macrophages suppresses metastasis and angiogenesis. Cancer Sci. 2013, 104, 1217-1225. [CrossRef] [PubMed]

134. Wu, W.; Luo, Y.; Sun, C.; Liu, Y.; Kuo, P.; Varga, J.; Xiang, R.; Reisfeld, R.; Janda, K.D.; Edgington, T.S.; et al. Targeting cell-impermeable prodrug activation to tumor microenvironment eradicates multiple drug-resistant neoplasms. Cancer Res. 2006, 66, 970-980. [CrossRef] [PubMed]

135. Guth, A.M.; Hafeman, S.D.; Elmslie, R.E.; Dow, S.W. Liposomal clodronate treatment for tumour macrophage depletion in dogs with soft-tissue sarcoma. Vet. Comp. Oncol. 2013, 11, 296-305. [CrossRef] [PubMed]

136. Germano, G.; Frapolli, R.; Belgiovine, C.; Anselmo, A.; Pesce, S.; Liguori, M.; Erba, E.; Uboldi, S.; Zucchetti, M.; Pasqualini, F.; et al. Role of macrophage targeting in the antitumor activity of trabectedin. Cancer Cell 2013, 23, 249-262. [CrossRef] [PubMed]

137. Allavena, P.; Germano, G.; Belgiovine, C.; D'Incalci, M.; Mantovani, A. Trabectedin: A drug from the sea that strikes tumor-associated macrophages. Oncoimmunology 2013, 2, e24614. [CrossRef] [PubMed]

138. Suzuki, E.; Kapoor, V.; Jassar, A.S.; Kaiser, L.R.; Albelda, S.M. Gemcitabine selectively eliminates splenic $\mathrm{Gr}-1^{+} / \mathrm{CD} 11 b^{+}$myeloid suppressor cells in tumor-bearing animals and enhances antitumor immune activity. Clin. Cancer Res. 2005, 11, 6713-6721. [CrossRef] [PubMed] 
139. Le, H.K.; Graham, L.; Cha, E.; Morales, J.K.; Manjili, M.H.; Bear, H.D. Gemcitabine directly inhibits myeloid derived suppressor cells in BALB/c mice bearing $4 \mathrm{~T} 1$ mammary carcinoma and augments expansion of $\mathrm{T}$ cells from tumor-bearing mice. Int. Immunopharmacol. 2009, 9, 900-909. [CrossRef] [PubMed]

140. Sasso, M.S.; Lollo, G.; Pitorre, M.; Solito, S.; Pinton, L.; Valpione, S.; Bastiat, G.; Mandruzzato, S.; Bronte, V.; Marigo, I.; et al. Low dose gemcitabine-loaded lipid nanocapsules target monocytic myeloid-derived suppressor cells and potentiate cancer immunotherapy. Biomaterials 2016, 96, 47-62. [CrossRef] [PubMed]

141. Vincent, J.; Mignot, G.; Chalmin, F.; Ladoire, S.; Bruchard, M.; Chevriaux, A.; Martin, F.; Apetoh, L.; Rebe, C.; Ghiringhelli, F. 5-fluorouracil selectively kills tumor-associated myeloid-derived suppressor cells resulting in enhanced T cell-dependent antitumor immunity. Cancer Res. 2010, 70, 3052-3061. [CrossRef] [PubMed]

142. Bruchard, M.; Mignot, G.; Derangere, V.; Chalmin, F.; Chevriaux, A.; Vegran, F.; Boireau, W.; Simon, B.; Ryffel, B.; Connat, J.L.; et al. Chemotherapy-triggered cathepsin B release in myeloid-derived suppressor cells activates the NLRP3 inflammasome and promotes tumor growth. Nat. Med. 2013, 19, 57-64. [CrossRef] [PubMed]

143. Wang, Z.; Liu, Y.; Zhang, Y.; Shang, Y.; Gao, Q. MDSC-decreasing chemotherapy increases the efficacy of cytokine-induced killer cell immunotherapy in metastatic renal cell carcinoma and pancreatic cancer. Oncotarget 2016, 7, 4760-4769. [PubMed]

144. Huang, X.; Cui, S.; Shu, Y. Cisplatin selectively downregulated the frequency and immunoinhibitory function of myeloid-derived suppressor cells in a murine B16 melanoma model. Immunol. Res. 2016, 64, 160-170. [CrossRef] [PubMed]

145. Espagnolle, N.; Barron, P.; Mandron, M.; Blanc, I.; Bonnin, J.; Agnel, M.; Kerbelec, E.; Herault, J.P.; Savi, P.; Bono, F.; et al. Specific inhibition of the VEGFR-3 tyrosine kinase by SAR131675 reduces peripheral and tumor associated immunosuppressive myeloid cells. Cancers 2014, 6, 472-490. [CrossRef] [PubMed]

146. Shao, B.; Wei, X.; Luo, M.; Yu, J.; Tong, A.; Ma, X.; Ye, T.; Deng, H.; Sang, Y.; Liang, X.; et al. Inhibition of a20 expression in tumor microenvironment exerts anti-tumor effect through inducing myeloid-derived suppressor cells apoptosis. Sci. Rep. 2015, 5, 16437. [CrossRef] [PubMed]

147. Khan, A.N.; Kolomeyevskaya, N.; Singel, K.L.; Grimm, M.J.; Moysich, K.B.; Daudi, S.; Grzankowski, K.S.; Lele, S.; Ylagan, L.; Webster, G.A.; et al. Targeting myeloid cells in the tumor microenvironment enhances vaccine efficacy in murine epithelial ovarian cancer. Oncotarget 2015, 6, 11310-11326. [CrossRef] [PubMed]

148. Stiff, A.; Trikha, P.; Wesolowski, R.; Kendra, K.; Hsu, V.; Uppati, S.; McMichael, E.; Duggan, M.; Campbell, A.; Keller, K.; et al. Myeloid-derived suppressor cells express bruton's tyrosine kinase and can be depleted in tumor-bearing hosts by ibrutinib treatment. Cancer Res. 2016, 76, 2125-2136. [CrossRef] [PubMed]

149. Ko, J.S.; Zea, A.H.; Rini, B.I.; Ireland, J.L.; Elson, P.; Cohen, P.; Golshayan, A.; Rayman, P.A.; Wood, L.; Garcia, J.; et al. Sunitinib mediates reversal of myeloid-derived suppressor cell accumulation in renal cell carcinoma patients. Clin. Cancer Res. 2009, 15, 2148-2157. [CrossRef] [PubMed]

150. Chen, H.M.; Ma, G.; Gildener-Leapman, N.; Eisenstein, S.; Coakley, B.A.; Ozao, J.; Mandeli, J.; Divino, C.; Schwartz, M.; Sung, M.; et al. Myeloid-derived suppressor cells as an immune parameter in patients with concurrent sunitinib and stereotactic body radiotherapy. Clin. Cancer Res. 2015, 21, 4073-4085. [CrossRef] [PubMed]

151. Draghiciu, O.; Boerma, A.; Hoogeboom, B.N.; Nijman, H.W.; Daemen, T. A rationally designed combined treatment with an alphavirus-based cancer vaccine, sunitinib and low-dose tumor irradiation completely blocks tumor development. Oncoimmunology 2015, 4, e1029699. [CrossRef] [PubMed]

152. Draghiciu, O.; Nijman, H.W.; Hoogeboom, B.N.; Meijerhof, T.; Daemen, T. Sunitinib depletes myeloid-derived suppressor cells and synergizes with a cancer vaccine to enhance antigen-specific immune responses and tumor eradication. Oncoimmunology 2015, 4, e989764. [CrossRef] [PubMed]

153. Medina-Echeverz, J.; Aranda, F.; Berraondo, P. Myeloid-derived cells are key targets of tumor immunotherapy. Oncoimmunology 2014, 3, e28398. [CrossRef] [PubMed]

154. Watkins, S.K.; Egilmez, N.K.; Suttles, J.; Stout, R.D. IL-12 rapidly alters the functional profile of tumor-associated and tumor-infiltrating macrophages in vitro and in vivo. J. Immunol. 2007, 178, 1357-1362. [CrossRef] [PubMed]

155. U'Ren, L.; Guth, A.; Kamstock, D.; Dow, S. Type I interferons inhibit the generation of tumor-associated macrophages. Cancer Immunol. Immunother. 2010, 59, 587-598. [CrossRef] [PubMed] 
156. Saccani, A.; Schioppa, T.; Porta, C.; Biswas, S.K.; Nebuloni, M.; Vago, L.; Bottazzi, B.; Colombo, M.P.; Mantovani, A.; Sica, A. P50 nuclear factor- $\kappa$ B overexpression in tumor-associated macrophages inhibits M1 inflammatory responses and antitumor resistance. Cancer Res. 2006, 66, 11432-11440. [CrossRef] [PubMed]

157. Hagemann, T.; Lawrence, T.; McNeish, I.; Charles, K.A.; Kulbe, H.; Thompson, R.G.; Robinson, S.C.; Balkwill, F.R. "Re-educating" tumor-associated macrophages by targeting NF-кB. J. Exp. Med. 2008, 205, 1261-1268. [CrossRef] [PubMed]

158. Yaddanapudi, K.; Putty, K.; Rendon, B.E.; Lamont, G.J.; Faughn, J.D.; Satoskar, A.; Lasnik, A.; Eaton, J.W.; Mitchell, R.A. Control of tumor-associated macrophage alternative activation by macrophage migration inhibitory factor. J Immunol 2013, 190, 2984-2993. [CrossRef] [PubMed]

159. Yang, W.; Lu, Y.; Xu, Y.; Xu, L.; Zheng, W.; Wu, Y.; Li, L.; Shen, P. Estrogen represses hepatocellular carcinoma (HCC) growth via inhibiting alternative activation of tumor-associated macrophages (TAMs). J. Biol. Chem. 2012, 287, 40140-40149. [CrossRef] [PubMed]

160. Zhang, X.; Tian, W.; Cai, X.; Wang, X.; Dang, W.; Tang, H.; Cao, H.; Wang, L.; Chen, T. Hydrazinocurcumin encapsuled nanoparticles "re-educate" tumor-associated macrophages and exhibit anti-tumor effects on breast cancer following STAT3 suppression. PLoS ONE 2013, 8, e65896. [CrossRef] [PubMed]

161. Hackler, L., Jr.; Ozsvari, B.; Gyuris, M.; Sipos, P.; Fabian, G.; Molnar, E.; Marton, A.; Farago, N.; Mihaly, J.; Nagy, L.I.; et al. The curcumin analog C-150, influencing NF-kB, UPR and Akt/Notch pathways has potent anticancer activity in vitro and in vivo. PLoS ONE 2016, 11, e0149832. [CrossRef] [PubMed]

162. Ahmad, R.; Raina, D.; Meyer, C.; Kufe, D. Triterpenoid CDDO-methyl ester inhibits the Janus-activated kinase-1 (JAK1) $\rightarrow$ signal transducer and activator of transcription-3 (STAT3) pathway by direct inhibition of JAK1 and STAT3. Cancer Res. 2008, 68, 2920-2926. [CrossRef] [PubMed]

163. Nagaraj, S.; Youn, J.I.; Weber, H.; Iclozan, C.; Lu, L.; Cotter, M.J.; Meyer, C.; Becerra, C.R.; Fishman, M.; Antonia, S.; et al. Anti-inflammatory triterpenoid blocks immune suppressive function of mdscs and improves immune response in cancer. Clin. Cancer Res. 2010, 16, 1812-1823. [CrossRef] [PubMed]

164. Fridlender, Z.G.; Jassar, A.; Mishalian, I.; Wang, L.C.; Kapoor, V.; Cheng, G.; Sun, J.; Singhal, S.; Levy, L.; Albelda, S.M. Using macrophage activation to augment immunotherapy of established tumours. Br. J. Cancer 2013, 108, 1288-1297. [CrossRef] [PubMed]

165. Albeituni, S.H.; Ding, C.; Liu, M.; Hu, X.; Luo, F.; Kloecker, G.; Bousamra, M., 2nd; Zhang, H.G.; Yan, J. Yeast-derived particulate $\beta$-glucan treatment subverts the suppression of myeloid-derived suppressor cells (MDSC) by inducing polymorphonuclear MDSC apoptosis and monocytic MDSC differentiation to apc in cancer. J. Immunol. 2016, 196, 2167-2180. [CrossRef] [PubMed]

166. Tian, J.; Ma, J.; Ma, K.; Guo, H.; Baidoo, S.E.; Zhang, Y.; Yan, J.; Lu, L.; Xu, H.; Wang, S. Beta-glucan enhances antitumor immune responses by regulating differentiation and function of monocytic myeloid-derived suppressor cells. Eur. J. Immunol. 2013, 43, 1220-1230. [CrossRef] [PubMed]

167. Huang, S.A.; Lie, J.D. Phosphodiesterase-5 (PDE5) inhibitors in the management of erectile dysfunction. Pharm. Ther. 2013, 38, 407-419.

168. Giannetta, E.; Feola, T.; Gianfrilli, D.; Pofi, R.; Dall'Armi, V.; Badagliacca, R.; Barbagallo, F.; Lenzi, A.; Isidori, A.M. Is chronic inhibition of phosphodiesterase type 5 cardioprotective and safe? A meta-analysis of randomized controlled trials. BMC Med. 2014, 12, 185. [CrossRef] [PubMed]

169. Serafini, P.; Meckel, K.; Kelso, M.; Noonan, K.; Califano, J.; Koch, W.; Dolcetti, L.; Bronte, V.; Borrello, I. Phosphodiesterase- 5 inhibition augments endogenous antitumor immunity by reducing myeloid-derived suppressor cell function. J. Exp. Med. 2006, 203, 2691-2702. [CrossRef] [PubMed]

170. Yin, Y.; Huang, X.; Lynn, K.D.; Thorpe, P.E. Phosphatidylserine-targeting antibody induces M1 macrophage polarization and promotes myeloid-derived suppressor cell differentiation. Cancer Immunol. Res. 2013, 1, 256-268. [CrossRef] [PubMed]

171. Pico de Coana, Y.; Poschke, I.; Gentilcore, G.; Mao, Y.; Nystrom, M.; Hansson, J.; Masucci, G.V.; Kiessling, R. Ipilimumab treatment results in an early decrease in the frequency of circulating granulocytic myeloid-derived suppressor cells as well as their arginase1 production. Cancer Immunol. Res. 2013, 1, 158-162. [CrossRef] [PubMed]

172. Meyer, C.; Cagnon, L.; Costa-Nunes, C.M.; Baumgaertner, P.; Montandon, N.; Leyvraz, L.; Michielin, O.; Romano, E.; Speiser, D.E. Frequencies of circulating MDSC correlate with clinical outcome of melanoma patients treated with ipilimumab. Cancer Immunol. Immunother. 2014, 63, 247-257. [CrossRef] [PubMed] 
173. Martens, A.; Wistuba-Hamprecht, K.; Geukes Foppen, M.; Yuan, J.; Postow, M.A.; Wong, P.; Romano, E.; Khammari, A.; Dreno, B.; Capone, M.; et al. Baseline peripheral blood biomarkers associated with clinical outcome of advanced melanoma patients treated with ipilimumab. Clin. Cancer Res. 2016, 22, 2908-2918. [CrossRef] [PubMed]

174. Duraiswamy, J.; Freeman, G.J.; Coukos, G. Therapeutic PD-1 pathway blockade augments with other modalities of immunotherapy T-cell function to prevent immune decline in ovarian cancer. Cancer Res. 2013, 73, 6900-6912. [CrossRef] [PubMed]

175. Dominguez-Soto, A.; de las Casas-Engel, M.; Bragado, R.; Medina-Echeverz, J.; Aragoneses-Fenoll, L.; Martin-Gayo, E.; van Rooijen, N.; Berraondo, P.; Toribio, M.L.; Moro, M.A.; et al. Intravenous immunoglobulin promotes antitumor responses by modulating macrophage polarization. J. Immunol. 2014, 193, 5181-5189. [CrossRef] [PubMed]

176. He, W.; Liang, P.; Guo, G.; Huang, Z.; Niu, Y.; Dong, L.; Wang, C.; Zhang, J. Re-polarizing myeloid-derived suppressor cells (MDSCs) with cationic polymers for cancer immunotherapy. Sci. Rep. 2016, 6, 24506. [CrossRef] [PubMed]

177. Fernandez, A.; Oliver, L.; Alvarez, R.; Fernandez, L.E.; Lee, K.P.; Mesa, C. Adjuvants and myeloid-derived suppressor cells: Enemies or allies in therapeutic cancer vaccination. Hum. Vaccines Immunother. 2014, 10, 3251-3260. [CrossRef] [PubMed]

178. Amoozgar, Z.; Goldberg, M.S. Targeting myeloid cells using nanoparticles to improve cancer immunotherapy. Adv. Drug Deliv. Rev. 2015, 91, 38-51. [CrossRef] [PubMed]

179. Shirota, Y.; Shirota, H.; Klinman, D.M. Intratumoral injection of CpG oligonucleotides induces the differentiation and reduces the immunosuppressive activity of myeloid-derived suppressor cells. J. Immunol. 2012, 188, 1592-1599. [CrossRef] [PubMed]

180. Seya, T.; Shime, H.; Matsumoto, M. Functional alteration of tumor-infiltrating myeloid cells in rna adjuvant therapy. Anticancer Res. 2015, 35, 4385-4392. [PubMed]

181. Chuang, C.M.; Monie, A.; Hung, C.F.; Wu, T.C. Treatment with imiquimod enhances antitumor immunity induced by therapeutic HPV DNA vaccination. J. Biomed. Sci. 2010, 17, 32. [CrossRef] [PubMed]

182. Mehta, A.R.; Armstrong, A.J. Tasquinimod in the treatment of castrate-resistant prostate cancer-Current status and future prospects. Ther. Adv. Urol. 2016, 8, 9-18. [CrossRef] [PubMed]

183. Shen, L.; Sundstedt, A.; Ciesielski, M.; Miles, K.M.; Celander, M.; Adelaiye, R.; Orillion, A.; Ciamporcero, E.; Ramakrishnan, S.; Ellis, L.; et al. Tasquinimod modulates suppressive myeloid cells and enhances cancer immunotherapies in murine models. Cancer Immunol. Res. 2015, 3, 136-148. [CrossRef] [PubMed]

184. Larghi, P.; Porta, C.; Riboldi, E.; Totaro, M.G.; Carraro, L.; Orabona, C.; Sica, A. The p50 subunit of NF-KB orchestrates dendritic cell lifespan and activation of adaptive immunity. PLOS ONE 2012, 7, e45279. [CrossRef] [PubMed]

185. Cubillos-Ruiz, J.R.; Baird, J.R.; Tesone, A.J.; Rutkowski, M.R.; Scarlett, U.K.; Camposeco-Jacobs, A.L.; Anadon-Arnillas, J.; Harwood, N.M.; Korc, M.; Fiering, S.N.; et al. Reprogramming tumor-associated dendritic cells in vivo using miRNA mimetics triggers protective immunity against ovarian cancer. Cancer Res. 2012, 72, 1683-1693. [CrossRef] [PubMed]

186. Draghiciu, O.; Lubbers, J.; Nijman, H.W.; Daemen, T. Myeloid derived suppressor cells-An overview of combat strategies to increase immunotherapy efficacy. Oncoimmunology 2015, 4, e954829. [CrossRef] [PubMed]

187. Rivera, L.B.; Meyronet, D.; Hervieu, V.; Frederick, M.J.; Bergsland, E.; Bergers, G. Intratumoral myeloid cells regulate responsiveness and resistance to antiangiogenic therapy. Cell Rep. 2015, 11, 577-591. [CrossRef] [PubMed]

188. Curtis, V.F.; Wang, H.; Yang, P.; McLendon, R.E.; Li, X.; Zhou, Q.Y.; Wang, X.F. A PK2/Bv8/PROK2 antagonist suppresses tumorigenic processes by inhibiting angiogenesis in glioma and blocking myeloid cell infiltration in pancreatic cancer. PLoS ONE 2013, 8, e54916. [CrossRef] [PubMed]

189. Paris, F.; Fuks, Z.; Kang, A.; Capodieci, P.; Juan, G.; Ehleiter, D.; Haimovitz-Friedman, A.; Cordon-Cardo, C.; Kolesnick, R. Endothelial apoptosis as the primary lesion initiating intestinal radiation damage in mice. Science 2001, 293, 293-297. [CrossRef] [PubMed]

190. Keefe, D.M.; Brealey, J.; Goland, G.J.; Cummins, A.G. Chemotherapy for cancer causes apoptosis that precedes hypoplasia in crypts of the small intestine in humans. Gut 2000, 47, 632-637. [CrossRef] [PubMed] 
191. Benoit, M.; Desnues, B.; Mege, J.L. Macrophage polarization in bacterial infections. J. Immunol. 2008, 181, 3733-3739. [CrossRef] [PubMed]

192. Mege, J.L.; Mehraj, V.; Capo, C. Macrophage polarization and bacterial infections. Curr. Opin. Infect. Dis. 2011, 24, 230-234. [CrossRef] [PubMed]

193. Allison, A.C. Immunosuppressive drugs: The first 50 years and a glance forward. Immunopharmacology 2000, 47, 63-83. [CrossRef]

194. Kienle, G.S. Fever in cancer treatment: Coley's therapy and epidemiologic observations. Glob. Adv. Health Med. 2012, 1, 92-100. [CrossRef] [PubMed]

195. Viaud, S.; Daillere, R.; Boneca, I.G.; Lepage, P.; Langella, P.; Chamaillard, M.; Pittet, M.J.; Ghiringhelli, F.; Trinchieri, G.; Goldszmid, R.; et al. Gut microbiome and anticancer immune response: Really hot sh*t! Cell Death Differ. 2015, 22, 199-214. [CrossRef] [PubMed]

196. Wesolowski, R.; Markowitz, J.; Carson, W.E., 3rd. Myeloid derived suppressor cells—A new therapeutic target in the treatment of cancer. J. Immunother. Cancer 2013, 1, 10. [CrossRef] [PubMed]

197. Buchanan, C.M.; Shih, J.H.; Astin, J.W.; Rewcastle, G.W.; Flanagan, J.U.; Crosier, P.S.; Shepherd, P.R. DMXAA (vadimezan, ASA404) is a multi-kinase inhibitor targeting VEGFR2 in particular. Clin. Sci. 2012, 122, $449-457$. [CrossRef] [PubMed]

198. Raymond, E.; Dalgleish, A.; Damber, J.E.; Smith, M.; Pili, R. Mechanisms of action of tasquinimod on the tumour microenvironment. Cancer Chemother. Pharmacol. 2014, 73, 1-8. [CrossRef] [PubMed]

199. Testa, U.; Masciulli, R.; Tritarelli, E.; Pustorino, R.; Mariani, G.; Martucci, R.; Barberi, T.; Camagna, A.; Valtieri, M.; Peschle, C. Transforming growth factor- $\beta$ potentiates vitamin D3-induced terminal monocytic differentiation of human leukemic cell lines. J. Immunol. 1993, 150, 2418-2430. [PubMed]

200. Young, M.R.; Ihm, J.; Lozano, Y.; Wright, M.A.; Prechel, M.M. Treating tumor-bearing mice with vitamin D3 diminishes tumor-induced myelopoiesis and associated immunosuppression, and reduces tumor metastasis and recurrence. Cancer Immunol. Immunother. 1995, 41, 37-45. [CrossRef] [PubMed]

201. Lathers, D.M.; Clark, J.I.; Achille, N.J.; Young, M.R. Phase 1B study to improve immune responses in head and neck cancer patients using escalating doses of 25-hydroxyvitamin D3. Cancer Immunol. Immunother. 2004, 53, 422-430. [CrossRef] [PubMed]

202. Gabrilovich, D.I.; Velders, M.P.; Sotomayor, E.M.; Kast, W.M. Mechanism of immune dysfunction in cancer mediated by immature Gr-1 ${ }^{+}$myeloid cells. J. Immunol. 2001, 166, 5398-5406. [CrossRef] [PubMed]

203. Mirza, N.; Fishman, M.; Fricke, I.; Dunn, M.; Neuger, A.M.; Frost, T.J.; Lush, R.M.; Antonia, S.; Gabrilovich, D.I. All-trans-retinoic acid improves differentiation of myeloid cells and immune response in cancer patients. Cancer Res. 2006, 66, 9299-9307. [CrossRef] [PubMed]

204. Lee, M.; Park, C.S.; Lee, Y.R.; Im, S.A.; Song, S.; Lee, C.K. Resiquimod, a TLR7/8 agonist, promotes differentiation of myeloid-derived suppressor cells into macrophages and dendritic cells. Arch. Pharm. Res. 2014, 37, 1234-1240. [CrossRef] [PubMed]

205. Nakanishi, Y.; Nakatsuji, M.; Seno, H.; Ishizu, S.; Akitake-Kawano, R.; Kanda, K.; Ueo, T.; Komekado, H.; Kawada, M.; Minami, M.; et al. COX-2 inhibition alters the phenotype of tumor-associated macrophages from M2 to M1 in Apc Min/+ mouse polyps. Carcinogenesis 2011, 32, 1333-1339. [CrossRef] [PubMed]

206. Na, Y.R.; Yoon, Y.N.; Son, D.I.; Seok, S.H. Cyclooxygenase-2 inhibition blocks M2 macrophage differentiation and suppresses metastasis in murine breast cancer model. PLoS ONE 2013, 8, e63451. [CrossRef] [PubMed]

207. Sinha, P.; Ostrand-Rosenberg, S. Myeloid-derived suppressor cell function is reduced by withaferin A, a potent and abundant component of Withania somnifera root extract. Cancer Immunol. Immunother. 2013, 62, 1663-1673. [CrossRef] [PubMed]

208. Srivastava, M.K.; Sinha, P.; Clements, V.K.; Rodriguez, P.; Ostrand-Rosenberg, S. Myeloid-derived suppressor cells inhibit T-cell activation by depleting cystine and cysteine. Cancer Res. 2010, 70, 68-77. [CrossRef] [PubMed]

209. Ye, C.; Geng, Z.; Dominguez, D.; Chen, S.; Fan, J.; Qin, L.; Long, A.; Zhang, Y.; Kuzel, T.M.; Zhang, B. Targeting ornithine decarboxylase by alpha-difluoromethylornithine inhibits tumor growth by impairing myeloid-derived suppressor cells. J. Immunol. 2016, 196, 915-923. [CrossRef] [PubMed]

(C) 2016 by the authors; licensee MDPI, Basel, Switzerland. This article is an open access article distributed under the terms and conditions of the Creative Commons Attribution (CC-BY) license (http:/ / creativecommons.org/licenses/by/4.0/). 